\title{
Regulation by catastrophe insurance: A comparative study
}

Citation for published version (APA):

He, Q., \& Faure, M. (2018). Regulation by catastrophe insurance: A comparative study. Connecticut Insurance Law Journal, 24(2), 189-243. https://doi.org/10.2139/ssrn.3089498

Document status and date:

Published: 01/03/2018

DOI:

10.2139/ssrn.3089498

Document Version:

Publisher's PDF, also known as Version of record

Document license:

Taverne

Please check the document version of this publication:

- A submitted manuscript is the version of the article upon submission and before peer-review. There can be important differences between the submitted version and the official published version of record.

People interested in the research are advised to contact the author for the final version of the publication, or visit the DOI to the publisher's website.

- The final author version and the galley proof are versions of the publication after peer review.

- The final published version features the final layout of the paper including the volume, issue and page numbers.

Link to publication

\footnotetext{
General rights rights.

- You may freely distribute the URL identifying the publication in the public portal. please follow below link for the End User Agreement:

www.umlib.nl/taverne-license

Take down policy

If you believe that this document breaches copyright please contact us at:

repository@maastrichtuniversity.nl

providing details and we will investigate your claim.
}

Copyright and moral rights for the publications made accessible in the public portal are retained by the authors and/or other copyright owners and it is a condition of accessing publications that users recognise and abide by the legal requirements associated with these

- Users may download and print one copy of any publication from the public portal for the purpose of private study or research.

- You may not further distribute the material or use it for any profit-making activity or commercial gain

If the publication is distributed under the terms of Article $25 \mathrm{fa}$ of the Dutch Copyright Act, indicated by the "Taverne" license above, 
2018

Regulation By Catastrophe Insurance: A Comparative Study

Qihao He

Michael Faure

Follow this and additional works at: https://opencommons.uconn.edu/cilj

Part of the Insurance Law Commons

\section{Recommended Citation}

He, Qihao and Faure, Michael, "Regulation By Catastrophe Insurance: A Comparative Study" (2018).

Connecticut Insurance Law Journal. 12.

https://opencommons.uconn.edu/cilj/12 


\title{
REGULATION BY CATASTROPHE INSURANCE: A COMPARATIVE STUDY
}

\author{
QIHAO HE \& MiCHAEL FAURE*
}

\begin{abstract}
$* * *$
Under the influence of climate-related extremes, the world is exposed to more and more catastrophe risks. Increasingly it is held that the government alone may not be able to adequately prevent disaster risks; a combination of public and private regulation is therefore warranted. Regulation via insurance may help to realize the goal of disaster risk reduction and to mitigate the corresponding losses. In this article we identify five regulatory tools - risk-based pricing, contract design, loss prevention services, claim management, and refusal to insure - that can be used by catastrophe insurers with the aim of disaster risk reduction. Subsequently, we explore how these tools are used in practice by insurers in five countries: United Kingdom, United States, France, Japan, and Turkey. In doing so, we find that regulation through catastrophe insurance could have a positive effect on disaster risk reduction. However, the possibilities to regulate by insurance are in many countries de facto limited as a result of state intervention. Finally, we discuss the possibility and feasibility of regulation by catastrophe insurance in China, where it is not yet utilized.
\end{abstract}

* Qihao He, Associate Professor of Law, China University of Political Science and Law (CUPL), College of Comparative Law. Beijing, China; Michael G. Faure, Professor of Comparative and International Environmental Law, Maastricht University, and Professor of Comparative Private Law and Economics, Erasmus University Rotterdam, The Netherlands.

We are grateful to the participants in the meeting of the Malta Legal Forum on Adaptation to Climate Change (Brugge, Belgium, 29-31 May 2016) for useful comments on an earlier version of this paper. We are equally grateful to Chihching Lan (Erasmus University Rotterdam, the Netherlands) for useful research assistance. Qihao thanks the financial support from International Trade and Finance Law Institute, UIBE in Beijing, and Comparative Private Law Innovation Project（比较私法的域 外经验与本土借鉴) of CUPL. 


\section{INTRODUCTION}

According to Beck the current era is characterized as a "risk society". ${ }^{1}$ Under the influence of climate extremes and other natural disasters, the world is exposed to more and more catastrophe risks. ${ }^{2}$ Although catastrophe risk events occur infrequently, such events result in significant human and financial losses. There is increasing attention not only to the question of how to compensate victims, but also to how compensation mechanisms, including insurance, can stimulate disaster risk reduction. ${ }^{3}$

Increasingly insurance is seen as a tool to "outsource" public regulation. ${ }^{4}$ In order to remedy the risk of moral hazard, inherent in any insurance contract, insurers "regulate" how organizations and individuals should deal with specific risks. ${ }^{5}$ Private insurance can act not only as a form of post-disaster relief but also as a form of private regulation-a contractual

${ }^{1}$ Ulrich Beck, Risk Society: Towards a New Modernity, THEORY, CULTURE \& SOC'Y SERIES (1992).

2 Data from large reinsurers show that the amounts and damage resulting from both man-made and natural disasters have been increasing over the past 30 years. See Lucia Bevere, Kristen Orwig \& Rajeev Sharan, Natural Catastrophes and Man-made Disasters in 2014: Convective and Winter Storms Generate Most Losses, SWISS RE INSTITUTION (2015), http://www.actuarialpost.co.uk/downloads/cat_1/sigma2_2015_en.pdf; Munich Re, Topics GEO National catastrophes $201 \overline{3}$ Analyses, assessments, positions (2014), http://www.munichre.com/site/corporate/ get/documents_E1043212252/mr/assetpool.shared/Documents/5_Touch/ Publications/302-08121 en.pdf.

${ }^{3}$ For example, The 2005 Hyogo Framework for Action highlights the urgency to advance the expansion of insurance markets to finance risk following a natural disaster. See J. David Cummins \& Oliver Mahul, Catastrophe Risk Financing in Developing Countries, THE WORLD BANK (2009); In the EU the Green Paper on the insurance of natural and man-made disasters equally pays attention to the ability of insurance to provide compensation and to stimulate risk-mitigating behavior. See Enhance, Green Paper on The Insurance of Natural and Man-Made Disasters, (COM (2013) 213 final) (2013).

${ }^{4}$ Omri Ben-Shahar \& Kyle D. Logue, Outsourcing Regulation: How Insurance Reduces Moral Hazard, 111 MICH. L. REV. 197, 200 (2012).

5 Steven Shavell, On Moral Hazard and Insurance, 93 Q.J. ECON. 541 (1979). 
device controlling and motivating behavior prior to the occurrence of a loss. ${ }^{6}$ Insurance is a well-known tool of risk management that addresses three aspects of risk management: risk assessment (or risk analysis), risk control, and risk financing. ${ }^{7}$ From society's perspective, insurance has at least two important functions. The first is that it can spread risks over a larger community and thus compensate risk-averse individuals exposed to risky activities through risk pooling and risk shifting. A second function is that by controlling the moral hazard, risk insurers also regulate policyholders' behavior and can thus contribute to risk reduction. Insurers can have these important functions also for catastrophe risks, provided specific conditions are met. ${ }^{8}$ The increasing amount of catastrophe losses is to a large extent due to an increasing contact between mankind and natural events. As a result of growing demographic pressures, there has been an increasing movement of population to high-risk areas, such as the coastal areas in Florida. This combined with aging infrastructure and low levels of public and private investment in disaster risk reduction increases the losses due to catastrophes. Insurance can, so we will argue, play an important role in preventing disaster losses and mitigating losses after a disaster has occurred. Given the increasing exposure of the population to catastrophe losses, the importance of insurance as a tool to regulate risky behavior only increases. ${ }^{9}$ Once insurers underwrite catastrophe risk, they have every reason to try to reduce their payouts. Therefore, regulation by insurance may help realize the goal of disaster risk reduction and the corresponding losses.

${ }^{6}$ Omri Ben-Shahar \& Kyle Logue, The Perverse Effects of Subsidized Weather Insurance, 68 STAN. L. REV. 571 (2016).

7 J. FrançOIS OUTREVILle, TheORY AND PRACTICE OF INSURANCE 45-64 (Kluwer Academic Publisher ed. 1998); ROB THOYTS, InSURANCE THEORY AND PRACTICE 286-295 (Routledge ed., 2010); EMMETT J. VAUGHAN \& THERESE M. VAUGHAN, FundAMENTALS OF RISK AND INSURANCE 16 (Judith Joseph et al. eds., 10th ed. 2007).

${ }^{8}$ George L. Priest, The Government, the Market, and the Problem of Catastrophic Loss, 12 J. RISK \& UNCERTAINTY 219 (1996).

${ }_{9}$ Erwann Michel-Kerjan, Have We Entered an Ever-Growing Cycle on Government Disaster Relief?, Presentation to U.S. Senate Committee on Small Business and Entrepreneurship (2013). 
Although there is general agreement on the important contribution of insurers to disaster risk reduction, less is known about the precise instruments and techniques used by insurers to achieve disaster risk reduction. This Article identifies under which specific conditions insurance can function as a substitute for, or a complement to, government regulation of catastrophe risks associated with natural disasters. This Article identifies five regulatory techniques of catastrophe insurance that may complement, and in some cases perhaps even outperform, government regulation by creating incentives for optimal behavior for individuals and organizations. The Article then compares five middle to high-income countries - the United Kingdom, the United States, France, Japan, and Turkey-in which catastrophe risks are regulated by insurance. In this comparison, we analyze the role of the state in facilitating regulation through insurance by examining to what extent the tools to control moral hazard are encouraged or restricted by government regulation.

In Part II we review the literature describing how, specifically in the field of catastrophe insurance, insurers can exercise regulatory functions aiming at disaster risk reduction. In Part III we discuss five specific tools that can contribute to disaster risk reduction. Part IV provides examples of the use of those regulatory techniques in five different countries, both developed and developing. Part $\mathrm{V}$ provides a comparative discussion concerning the effectiveness of regulation via catastrophe insurance. Finally, Part VI discusses the possibility and feasibility of regulation by catastrophe insurance in China, where it is not yet utilized.

\section{INSURANCE AS A TOOL OF DISASTER RISK REDUCTION}

Any insurance contract, whether it is first party (victim) insurance or third party (liability) insurance is vulnerable to the moral hazard risk. Many stress the fact that insurance leads to moral hazard. Therefore it is at first blush often considered as increasing risk, rather than as a tool of risk 
reduction. ${ }^{10}$ Moral hazard is the tendency of insureds from vulnerable areas to exercise less care in avoiding losses than they would if the losses were not covered by insurers. ${ }^{11}$ Admittedly, it is only logical for the insureds to change their behavior as soon as the risk is fully removed from them. ${ }^{12}$ Such changes in behavior is in that sense not "immoral". The moral hazard risk is especially problematic as far as liability insurance is concerned. The reason is that an exposure to liability provides incentives for the prevention of accidents to potential insurers. Moral hazard could endanger those incentives for prevention and may therefore have socially negative consequences. In that case liability insurance should be prohibited since it would increase risk in society. ${ }^{13}$ Remedies for moral hazard are available. The best option is monitoring by the insurer and a corresponding adaptation of premium conditions. ${ }^{14}$ This solution is thought to be the best since risk would be completely removed from a risk adverse individual. The second-best option is still to expose an insured partially to risk, either by applying deductibles or an upper limit on coverage. ${ }^{15}$ In practice, insurers will apply a combination of different techniques (risk differentiation, specific conditions in policies and deductibles) to control moral hazard. ${ }^{16}$ It is precisely through this control of the moral hazard risk that insurers will act as de facto regulators and invest in risk prevention. This article will

${ }^{10}$ See Bengt Hölmstrom, Moral Hazard and Observability, 10 Bell J. Econ. 74 (1979).

${ }^{11}$ Kenneth S. Abraham \& Daniel Schwarcz, InSURANCE LAW AND REGULATION, 7 (6th ed. 2015).

${ }^{12}$ Mark Pauly, The Economics of Moral Hazard: Comment, 58 AMER. ECON. REV. 531(1968).

${ }^{13}$ Steven Shavell, On Liability and Insurance, 13 BELL J. ECON. 120, 120-32 (1982).

${ }^{14}$ This can take place ex ante (through a so-called risk classification) or ex post (after the accident) through experience rating. The latter implies effectively that the premium would be increased after a reported incident.

${ }^{15}$ Hsin-Chun Wang, Adaptation to Climate Change and Insurance Mechanism: A Feasible Proposal Based on a Catastrophe Insurance Model for Taiwan, 9 NAT'L TAIWAN U. L. REV. 317 (2014).

${ }^{16}$ See Shavell, supra note 5; Steven Shavell, On the Social Function and Regulation of Liability Insurance, 25 GENEVA PAPERS ON RISK \& INS. $166,168-70$ (2000). 
show that through this control of the moral hazard, risk insurers are viewed as private (risk) regulators and that through this control of moral hazard they can contribute to disaster risk reduction.

A. Insurance as Private (Risk) Regulation

Regulation by insurance is not the same as insurance regulation. The latter is a classic topic of insurance law, and mainly discusses how the insurance business and organizations are regulated by administrative agencies. ${ }^{17}$ On the other hand, regulation by insurance explores the potential value of insurance as a complement to, or substitute for, the State. ${ }^{18}$ There is an increasing interest in the regulatory potential of insurance companies both in academic literature as well as at the policy level.

A considerable amount of literature has been devoted to discussing regulation by insurance. As far back as 1986, Reichman explored insurance as a social control tool to regulate crime risk. ${ }^{19}$ More recently, Abraham offered an overview and critique of modern conceptions of insurance based on the debates about insurance and insurance law in recent decades; one

${ }^{17}$ There are many possible ways to describe insurance regulation. For example, the function of insurance regulation describes seven main functional divisions: licensing, taxation, solvency, rates, forms, access and availability, and market conduct; theoretical justifications of insurance regulation present information problems, externalities, opportunism and egalitarian or distributional objectives to justify regulation. See TOM Baker \& Kyle D. Logue, Insurance LaW \& Policy: Cases MATERIALS \& PROBLEMS 573-580 (Vicki Been et al. eds., 3d ed. 2013).

${ }^{18}$ Some scholars prefer the term "governance by insurance." In this Article, governance by insurance is interchangeable with the term "regulation by insurance."

19 Nancy Reichman, Managing Crime Risks: Toward an Insurance Based Model of Social Control, in 8 RESEARCH IN LAW, DEVIANCE AND Social CONTROL 151-172 (Andrew T. Scull \& Stephen Spitzer eds., 1986). 
such conception is that of "insurance as governance," which corresponds to the idea of regulation by insurance. ${ }^{20}$

In 2002, Heimer discussed the cost and benefit of private regulation through insurance. ${ }^{21}$ In 2003, Ericson, Doyle, and Barry adopted a sociological perspective to explore insurance as governance, and documented how the insurance industry governs our lives and asserts insurance governing through nine interconnected dimensions. ${ }^{22}$ In 2004, Ericson and Doyle further applied their theoretical framework to four sets of risks that are governed by insurance: life, disability, earthquakes, and terrorism. ${ }^{23}$ They invented a new term for the insurance approach to natural catastrophe risk, "absorbing risk", which requires creating an infrastructure that can withstand the shock of a catastrophe. ${ }^{24}$ Consistent with the concept of absorbing risk, Baker urged the reconsideration of assessment approaches to catastrophe insurance to allow insurance institutions to manage the uncertainties of catastrophe risk. ${ }^{25}$

In 2005, Baker and Farrish initiated the discussion of the technique of firearms regulation by liability insurance. ${ }^{26}$ With gun violence

${ }^{20}$ Kenneth S. Abraham, Four Conceptions of Insurance, 161 U. PA. L. REV. 653 (2013); see also Jeffrey W. Stempel, The Insurance Policy as Social Instrument and Social Institution, 51 WM. \& MARY L. REV. 1489 (2009) (His argument seems to fit comfortably within the "insurance as governance" conception).

${ }^{21}$ Carol Heimer, Insuring More, Ensuring Less: The Costs and Benefits of Private Regulation through Insurance, in EMBRACING RISK: THE CHANGING CUlTURE OF INSURANCE AND RESPONSIBILITY 116-145 (Tom Baker \& Jonathan Simon eds. 2002).

22 See generally Richard V. ERICSON, AARON DOYLE, \& DEAN BARRY, INSURANCE AS GOVERNANCE (2003).

${ }^{23}$ See generally RICHARD V. ERICSON \& AARON DOYLE, UNCERTAIN BUSINESS: RISK, INSURANCE AND THE LIMITS OF KNOWLEDGE (U. Toronto Press 2004).

${ }^{24} \mathrm{Id}$.

${ }^{25}$ See generally Tom Baker, Embracing Risk, Sharing Responsibility, 56 DRAKE L. REV. 561 (2007).

${ }_{26}$ Tom Baker \& Thomas O. Farrish, Liability Insurance \& the Regulation of Firearms, in SUING THE GUN INDUSTRY: A BATTLE AT THE CROSSROADS OF GUN CONTROL AND MASS TORTS 292-314 (Timothy D. Lytton ed., 2005). 
dominating the headlines during the last several years, Kochenburger has argued that regulation by liability insurance could serve as a potentially valuable tool to address and reduce gun violence ${ }^{27}$ while Mocsary contends that the insurance regime is unlikely to attain this goal. ${ }^{28}$ Besides gun violence, Yin, Kunreuther, and White have examined how environmental liability insurance can reduce environmental accidents based on disaggregated (facility-level) data. ${ }^{29}$ Ben-Shahar and Logue have additionally explored regulation by insurance as a substitute for government regulation of safety in areas of products liability, workers' compensation, auto, homeowners, environmental liability and tax liability, and expand to yet unutilized areas, such as consumer protection, food safety, and financial statements. ${ }^{30}$ In 2003, Baker and Swedloff summarized regulation by liability insurance, and drew upon prior literature to examine four areas of liability and corresponding insuranceshareholder liability, automobile liability, gun liability, and medical professional liability - and developed a conceptual framework to guide qualitative research for lawyers' professional liability. ${ }^{31}$

In 2015, Talesh significantly widened the scope of regulation by insurance through the study of Employment Practices Liability Insurance ("EPLI"), explaining how insurance practices have transformed the moral logic of anti-discrimination law into the risk management logic of EPLI loss prevention advice. This study demonstrated how regulation by insurance does not simply consist of assessing how well liability insurance delivers a legal deterrence signal, but rather how it transforms that signal into loss

${ }_{27}$ Peter Kochenburger, Liability Insurance and Gun Violence, 46 CONN. L. REV. 1265, 1269-70 (2014).

${ }_{28}^{28}$ George Mocsary, Insuring Against Guns?, 46 CONN. L. REV. 1209, 1212-13 (2014).

${ }^{2}$ Haitao Yin, Howard Kunreuther \& Matthew W. White, Risk-Based Pricing and Risk-Reducing Effort: Does the Private Insurance Market Reduce Environmental Accidents?, 54 J. L. \& ECON. 325 (2011).

${ }^{30}$ Ben-Shahar \& Logue, supra note 4.

${ }^{31}$ Tom Baker \& Rick Swedloff, Regulation by Liability Insurance: From Auto to Lawyers Professional Liability, 60 UCLA L. REV. 1412 (2013). 
prevention. ${ }^{32}$ It is not only insurers that play a role as private regulators; recently it was stressed that reinsurance companies can also act as "silent regulators", ${ }^{33}$ particularly in exercising a regulatory influence on insurers. ${ }^{34}$ As we will show below, in the latter case there are often also hybrid constructions since catastrophe insurance is frequently offered by reinsurance pools in which the government equally participates.

\section{B. Disaster Risk Reduction by CONTROLLING Moral HAZARD}

These regulatory effects of insurance that have just been described generally can also be found in the area of catastrophe insurance. The danger of moral hazard can obviously also arise in the case of catastrophe insurance. As a result, insurers will exercise control on the behavior of the insured to remedy moral hazard. It is precisely that control that will also, in the field of catastrophes, provide effective incentives for disaster risk reduction. This has been well documented. Kunreuther and his colleagues at the Wharton Risk Management and Decision Processes Center have argued that insurance can be structured to improve the incentive to protect oneself against flood and hurricane damage. To achieve this goal, they proposed the idea of multi-year insurance contracts with risk-based premiums that could enable insurers to offer lower premiums for properties where measures have been taken to reduce risk. ${ }^{35}$ As for climate-related extremes, Telesetsky has

32 See generally Shauhin Talesh, Legal Intermediaries: How Insurance Companies Construct the Meaning of Compliance with Anti-Discrimination Laws, 37 U. DENVER L. \& POL'Y 209 (2015).

${ }^{33}$ Aviva Abramovsky, Reinsurance: The Silent Regulator?, 15 ConN. INS. L.J. 345, 348-49 (2009).

34 See generally Marcos Antonio Mendoza, Reinsurance as Governance: Governmental Risk Management Pools as a Study in the Governance Role Played by Reinsurance Institutions, 21 CONN. INS. L.J. 53 (2014).

35 See generally Howard Kunreuther, The Role of Insurance in Reducing Losses from Extreme Events: The Need for Public-Private Partnerships, 40 THE GENEVA PAPERS 741 (2015); Howard Kunreuther \& Erwann Michel-Kerjan, Managing Catastrophic Risks through Redesigned Insurance: Challenges and Opportunities, in HANDBOOK OF INSURANCE, 1-40 (G. Dionne. ed. 2012); Howard Kunreuther \& Mark Pauly, Insuring 
posited that third-party insurance that follows the polluter that pays principle could compel timely climate change mitigation on the part of major greenhouse gas emitters. ${ }^{36}$ Telesetsky has also explored how mandatory climate change catastrophe insurance can serve the goals of both corrective and distributive justice. Furthermore, Faure and Bruggeman, from the perspective of compensation, have documented how first-party insurance can constitute a viable alternative to government compensation while victims can also benefit from preventative incentives. ${ }^{37}$

Empirical evidence supports this literature. An empirical study of catastrophe insurance markets in Germany and the U.S. utilizing field survey data, suggests the opposite of a moral hazard effect. ${ }^{38}$ This study responds to the theoretical hypothesis that recognizes that insurers have the capacity and means to manage moral hazard. ${ }^{39}$ The findings from Germany conclude that "individuals with flood insurance are more likely to have undertaken one of the suggested flood coping measures than uninsured households". ${ }^{40}$ This conclusion is supported by the evidence from the U.S.,

Against Catastrophes, in THE KNOWN, THE UNKNOWN AND THE UNKNOWABLE IN FINANCIAL RISK MANAGEMENT, 210-238 (F. X. Diebold, N. Doherty and R. Herring, eds., 2010).

36 See generally Anastasia Telesetsky, Insurance as a Mitigation Mechanism: Managing International Greenhouse Gas Emissions through Nationwide Mandatory Climate Change Catastrophe Insurance, 27 PACE ENVTL. L. REV. 691 (2010).

37 See generally Michael G. Faure, Insurability of Damage Caused by Climate Change: A Commentary, 155 U. PA. L. REV. 1875 (2007); Michael Faure \& Véronique Bruggeman, Catastrophic Risks and First-Party Insurance, 15 CONN. INS. L.J. 1 (2008).

${ }^{38}$ See generally Paul Hudson et al., Moral Hazard in Natural Disaster Insurance Markets: Empirical Evidence from Germany and the United States, 93 LAND ECON. 179, 179-208 (2017) (They conducted a comprehensive empirical study of risk selection in natural disaster insurance markets and asked whether disaster preparedness activities differ when people have natural disaster coverage. The statistical analyses are based on survey data of individual disaster insurance purchases and risk mitigation activities in Germany and the United States). note 4 .

39 See generally Shavell, supra note 5; Ben-Shahar \& Logue, supra

${ }^{40}$ See Hudson et al., supra note 38, at 181 ("Our analysis found that households with flood insurance suffer larger losses than uninsured 
which shows that households who are more likely to have flood insurance and homeowners policies that cover wind damage, engage in more ex ante property risk reduction behavior on hurricane preparedness. ${ }^{41}$ This is equally evident in Switzerland where a public monopoly insurance exists with mandatory participation that has been shown to incentivize risk reduction. ${ }^{42}$

There is an interesting cooperation between the State and insurers. Catastrophe risk may result in significant human and financial losses, and is therefore an issue that the State must address. The State reaches out to the insurance industry to regulate and absorb some of the catastrophe risk. Additionally, the State needs the cooperation of the insurance industry because of the low-frequency but high-impact nature of catastrophe risk, and the complexity of establishing affordable and sustainable management and compensation arrangements. ${ }^{43}$ Moreover, the State often creates a regulatory vacuum by refusing to take up contentious questions in which activities related to catastrophe risk should be encouraged, permitted, or proscribed ${ }^{44}$ The insurance industry can address the problems caused by catastrophe risk and fill the regulatory vacuum by providing the technical apparatus needed for risk reduction and loss compensation. ${ }^{45}$ In turn the State cooperates with the insurance industry for catastrophe losses of which the expected damage may exceed amounts that could be insured on normal

households due to their higher hazard level rather than due to moral hazard, which to the best of our knowledge has not been shown before.").

${ }^{41}$ Hudson et al., supra note 38.

${ }^{42}$ Paul Raschky et al., Alternative Financing and Insurance Solutions for Natural Hazards: A Comparison of Different Risk Transfer Systems in Three Countries - Germany, Austria and Switzerland - Affected by the August 2005 Floods, ReSEARCHGATE, 13-14， 17 (2009); Gebhard Kirchgässner, On the Efficiency of a Public Insurance Monopoly: The Case of Housing Insurance in Switzerland, in PUBLIC ECONOMICS AND PUBLIC CHOICE 221-226 (Baake P \& Bork R eds., 2007).

${ }_{43}$ See generally Youbaraj Paudel, A Comparative Study of Public - Private Catastrophe Insurance Systems: Lessons from Current Practices, 37 THE GENEVA PAPERS 257 (2012).

${ }_{44}^{4}$ See generally Heimer, supra note 21.

45 See generally Tom Baker, Insurance in Sociolegal Research, 6 ANN. REV. L. \& SOC. SCI. 433 (2010). 
insurance and reinsurance markets. In that case the State provides compensation of an upper layer as a reinsurer of last resort. ${ }^{46}$ In many legal systems there are various mutual dependencies between the state and the insurance industry in protecting against natural disasters. On the one hand the State depends upon the insurance industry to provide primary cover and to provide incentives for disaster risk reduction. Insurers on the other hand rely on primary investments by the state in disaster risk reduction (for example building dikes and levees) and regulating disaster risk reduction. Insurers also depend upon the state as a reinsurer of last resort to provide an upper layer of cover. ${ }^{47}$ Moreover, in some cases reinsurance is provided by pools which have a hybrid character as they consist of both reinsurers and the government. ${ }^{48}$ Two interesting questions arise in that respect. The first question relates to the precise technical tools used by insurers to provide incentives for disaster risk reduction. The second question asks whether the government equally plays a role (in interaction with insurers) in providing those incentives for disaster risk reduction. Those questions will be the subject of the next section.

${ }^{46}$ See generally Johanna Hjalmarsson \& Mateusz Bek, Legislative and Regulatory Methodology and Approach: Developing Catastrophe Insurance in China, in INSURANCE LAW IN CHINA (Johanna Hjalmarsson \& Dingjing Huang eds., 2015); Joanne Linnerooth-Bayer et al, Insurance against Losses from Natural Disasters in Developing Countries: Evidence, Gaps and the Way Forward, 1 J. INTEGRATED DisASTER RISK MGMT. 59 (2011); Véronique Bruggeman, Michael G. Faure and Karine Fiore, The Government as Reinsurer of Catastrophe Risks?, 35 THE GENEVA PAPERS 369-390 (2010).

${ }^{47}$ See generally Véronique Bruggeman, Michael Faure \& Tobias Heldt, Insurance Against Catastrophe: Government Stimulation of Insurance Markets for Catastrophic Events, 23 DUKE ENVTL. L. \& POL'Y F. 185 (2012).

48 See Mendoza, supra note 34. 


\section{REGULATORY TECHNIQUES OF CATASTROPHE INSURANCE}

As a private regulator, insurance operates stealthily by using technical tools to reduce moral hazard. ${ }^{49}$ As indicated these instruments to control moral hazard consist on the one hand of techniques to control the behavior of the insured via adapted policy conditions and on the other hand in partially exposing the insured to risk. ${ }^{50}$ In some of the literature previously discussed a further refinement of the regulatory techniques of insurance has been made leading to the following taxonomy. ${ }^{51}$ These technical tools, which almost all insurers use to one degree or another, include risk-based pricing, contract design (e.g. limits, deductibles, copayments, and exclusions), loss prevention, claim management, and refusal to insure. Of course, not all of those technical tools will be used by catastrophe insurers to the same extent. However, this taxonomy provides a good categorization of the types of technical tools usually employed in catastrophe insurance to control moral hazard.

\section{A. RISK-BASED PRICING}

Risk-based pricing is considered to be the most basic technique for creating incentives to reduce risk. ${ }^{52}$ Insurers set premiums to reflect underlying risk levels in order to provide individuals incentives to mitigate losses. ${ }^{53}$ Indeed, insurers often adopt feature ratings ${ }^{54}$ and experience

${ }^{49}$ Heimer, supra note 21.

50 Shavell, supra note 5.

${ }^{51}$ Baker \& Farrish, supra note 26; Baker \& Swedloff, supra note 31; Ben-Shahar \& Logue, supra note 4; Victor P. Goldberg, The Devil Made Me Do It: The Corporate Purchase of Insurance, 5 Rev. L. \& Econ. 541 (2009).

${ }^{52}$ Ben-Shahar \& Logue, supra note 4.

${ }^{53}$ Peter Molk, Private Versus Public Insurance for Natural Hazards: Individual Behavior's Role in Loss Mitigation, in RISK ANALYSIS OF NATURAL HAZARDS 265-277 (Paolo Gardoni et al. eds., 2015).

${ }^{54}$ Feature rating means insurers examine the insured's individual risk characteristics and adjust premiums accordingly; experience rating means 
ratings in order to signal premium loss prevention. Charging lower premiums to careful policyholders induces them to reduce exposure to claims in order to avoid higher premiums in the future..$^{55}$ For example, environmental liability policies reward policyholders with premium discounts if they take loss prevention measures, such as replacing fuel tanks constructed of corrosion-prone material; by contrast, the premium will be raised by ten to twenty percent due to a prior leak of the fuel tank. ${ }^{56}$ Risk-based pricing is therefore quite a straightforward tool to reduce moral hazard.

In the field of catastrophe insurance, risk-based premiums enable insurers to provide discount to residents adopting cost-effective mitigation measures, and thus provide a clear signal to those currently residing in hazard-prone areas. ${ }^{57}$ It also urges homeowners who plan to settle in hazard-prone areas to reconsider their choice of location and to reduce their vulnerability to catastrophes. ${ }^{58}$ Such regulation may not work if insurance premiums are not risk-based. Furthermore for insurers, risk-based pricing not only assures adequate returns to investors, but also helps guarantee solvency when catastrophes happen. ${ }^{59}$ The relationship with public regulation is clear: to the extent that public regulation would prevent insurers from charging risk-based premiums this tool aiming at disaster risk reduction could not be employed in an optimal manner.

insurers gather information about the insured's loss experience during the course of the policy period and use that information either to make retroactive pricing adjustments or prospective pricing adjustments for future policy periods. See Ben-Shahar \& Logue, supra note 4 at 206.

55 Baker \& Swedloff, supra note 31, at 1419.

56 See Yin, Kunreuther \& White, supra note 29.

${ }^{57}$ Howard Kunreuther, Professor, Univ. of Pa., Testimony before the Subcommittee on Economic Growth, Tax and Capital Access of the House Small Business Committee: Oversight of the SBA's Disaster Assistance Program and Examining Changes Proposed by H.R. 3042 - The Disaster Loan Fairness Act of 2011, (Feb. 16, 2012), http://smallbusiness.house.gov /uploadedfiles/kunreuther_testimony.pdf.

${ }_{58}$ Kunreuther \& Michel-Kerjan, supra note 35.

59 Id. 


\section{B. Contract Design}

Contract design can also be used to regulate risk both directly and indirectly, by including such elements as deductibles, copayments, coverage amount limits, and exclusions. Deductibles and copayments can mitigate moral hazard directly by preventing policyholders from shielding themselves entirely from loss. ${ }^{60}$ This is one of the tools to control moral hazard: exposing the insured partially to risk will provide incentives for adequate prevention to the insured. If indeed a portion of the risk remains with the insured, they will exercise greater vigilance. ${ }^{61}$ Exclusions can be seen as an indirect way to regulate policyholders, as it excludes certain types of risk or claims from coverage. For example, intentional harm is commonly excluded from liability insurance policies; environmental claims, too, are often excluded from general liability insurance ("CGL") policies. Deductibles are, moreover, a good technique to remedy adverse selection: good risks can signal their lower exposure to risk by choosing a higher deductible.

Furthermore, using the tools of contract design places a lower burden of information on insurers than when using risk-based pricing. It may also be comparatively efficient in attracting insureds to adopt cheap measures of risk mitigation. ${ }^{62}$ Again, from a regulatory perspective the ability of insurers to incentivize disaster risk reduction via an optimal contract design may be jeopardized as a result of public regulation (e.g. limiting the amount of the deductible).

60 "Deductibles require insureds to pay a fixed amount 'out of pocket' to cover insured losses before the insurance coverage kicks in to cover insured losses thereafter. Copayments typically require insureds to bear some fraction of each covered loss claim filed by an insured". See Ben-Shahar \& Logue, supra note 4 at 209 n.30.; see also Baker \& Swedloff, supra note 31 at 1429-30.

${ }^{61} \mathrm{Id}$. at 1420 .

62 See generally Ronen Avraham, The Law and Economics of Insurance Law-A Primer, 19 CONN. INS. L.J. 29 (2012). 
C. LOSS PREVENTION

Providing loss prevention services is an obvious form of regulation, because it permits insurers to advise policyholders on how to modify their behavior in order to mitigate and avoid losses. ${ }^{63}$ In other words, loss prevention services can serve as ex ante regulation by insurance. Insurers have an advantage over policyholders in identifying the best ways to mitigate risk and avoid losses, because they are able to collect more data on claims and harms. Insurers, therefore, will eventually benefit from loss prevention services because they have to pay for the loss based on the policy. Additionally, active engagement in loss prevention will enable insurers to identify insureds with lower than average moral hazard and underwrite "good" risks.

Insurers can promote loss prevention in a variety of ways, all of which are potentially applicable to catastrophe insurance. ${ }^{64}$ Insurers may monitor the insureds through loss prevention during the course of the insurance relationship; ${ }^{65}$ they may conduct research and disseminate new loss-prevention methods; ${ }^{66}$ they may cooperate with the State, and promote the legislation of loss prevention laws and regulations, ${ }^{67}$ lastly, insurers may establish underwriting procedures that make loss prevention activities a precondition to obtaining insurance. ${ }^{68}$

${ }_{63}$ See generally Baker \& Swedloff, supra note 31.

64 George M. Cohen, Legal Malpractice Insurance and Loss Prevention: A Comparative Analysis of Economic Institutions, 4 CONN. INS. L.J. 305 (1997); Baker \& Farrish, supra note 26.

${ }^{65}$ For example, in the auto insurance context, insurers monitor the insureds' repair service to mitigate loss.

66 For example, the homeowners' insurance industry has its own association (The Insurance Institute for Business and Home Safety) researching and promulgating various ways of making commercial properties and homes safer from all sorts of hazards.

${ }^{67}$ For example, insurers attempt to upgrade and enhance the content and enforcement of state and local building codes.

${ }^{68}$ For example, most insurance policies require the insureds to take all reasonable post-accident activities to mitigate losses or else forfeit coverage. See ROBERT H. JERRY, II \& DOUGLAS R. RICHMOND, The 
Hurricane Andrew changed the manner in which insurers use prevention loss services in catastrophe insurance. Before that event, insurers did not promote loss prevention services because they thought these services would prevent them from raising premiums and increasing their profits. ${ }^{69}$ After Hurricane Andrew, the situation has changed, and insurers have taken a new approach to loss prevention services as they now feel that they have the potential to initiate fundamental behavioral change among the insureds. Hurricane Andrew has led insurers to engage with laws and regulations, as it was understood that the loss of houses incurred by disasters is due largely to lack of enforcement of building codes. ${ }^{70}$ Consequently, the Insurance Institute for Property Loss Reduction (now the Insurance Institute for Business \& Home Safety) was established to promote building code inspections and enforcement, and to initiate a Code Effectiveness Grading Schedule, which uses the Fire Suppression Rating Program as a prototype. ${ }^{71}$ The insurers' approach has changed from a financial point of view as well, because they have to demand high premiums in order to underwrite highly risky activities which will lead them to a disadvantaged position in the market. ${ }^{72}$

Some public-private partnership catastrophe insurance programs expand loss prevention services by providing information on the benefits of risk mitigation to insureds. The legislation for both the Florida Hurricane Catastrophe Fund and the California Earthquake Authority, for example, demands of insurers to promote loss prevention services among their clienteles. $^{73}$

Insurer's Duty to Pay Proceeds, in UNDERSTANDING INSURANCE LAW 637 (4th ed. 2007).

${ }^{69}$ See generally Robert Hunter, Insuring Against Natural Disaster, 12 J. OF INS. REG. 467 (1994).

70 See Howard Kunreuther, Mitigating Disaster Losses through Insurance, 12 J. OF RISK AND UNCERTAINTY 171 (1996).

${ }^{71} I d$.

${ }^{72}$ Telesetsky, supra note 36.

${ }^{73}$ DWIGHT JAFFEE, Catastrophe Insurance, in RESEARCH HANDBOOK ON THE ECONOMICS OF INSURANCE LAW, 160-89 (Daniel Schwarcz \& Peter Siegelman. eds., 2015). 
In the context of climate change, insurers have worked in tandem with scientists to identify technical and economic parameters of catastrophe risk and develop system-wide technologies of loss prevention. ${ }^{74}$ In addition, in order to realize the goal of loss prevention, insurers offer low premiums for low emissions operators as an incentive to adopt certain technologies and gradually reduce their emission. ${ }^{75}$

\section{Claim Management}

In addition to ex ante regulation, insurers also conduct ex post regulation through claim management. Generally speaking, policyholders often lack control over the cost of a claim, leaving its management in the hands of the insurers. ${ }^{76}$ Different lines of insurers operate different types of claim management. Liability insurers, due to their right and duty to defend and settle, can directly regulate the litigation process and thus mitigate ex post moral hazard. Because of their involvement in claim management and litigation, they can further apply such information in pricing, contract design, and loss prevention services. In workers' compensation insurance, since the employer bears the actual risk, insurers are only providing claims administration services based on their expertise in verifying, quantifying, and managing the claims and payments. ${ }^{77}$

In the case of catastrophe risks, the policyholders' inability to change the possibility of a natural disaster, alongside their ability to mitigate disaster losses, make claim management quite necessary to control ex post moral hazard. Catastrophe insurers, therefore, may employ an adjuster to investigate claimed losses, measure them, and negotiate payouts. Then they can review the adjuster's decisions and provide greater uniformity and predictability.

74 Peter A. Stott et. al, Human Contribution to the European Heatwave of 2003, 432 NATURE 610 (2004), https://www.nature.com/articles/nature03089.

${ }_{75}$ See Telesetsky, supra note 36.

76 Tom Baker, Liability Insurance Conflicts and Defense Lawyers: From Triangles to Tetrahedrons, 4 CONN. INS. L.J. 101, 107 (1997).

77 Ben Sahar \& Logue, supra note 4, at 213-14. 


\section{E. REFUSAL To INSURE}

The final technical tool used by insurers to regulate their insured is the refusal to insure. A refusal to provide insurance is especially important when the availability of insurance has been made a precondition to exercise a particular activity. There can be an obligation to take out insurance either based on regulation (mandatory insurance) or based on contract. An example of the latter constitutes homeowners insurance in the U.S. Before the mortgage contract is concluded, the mortgagor is required to obtain homeowners insurance or to relegate to the mortgagee to acquire such insurance. ${ }^{78}$ In this case, and presuming catastrophe insurance is mandatory in hazard-prone areas, the insurers' refusal to insure may have de facto control over the insureds, and may induce less risky behavior. A refusal to insure is of course more complex in systems, such as in France, ${ }^{79}$ where the purchase of disaster coverage is mandatory, or at least a mandatory complement to a voluntary homeowners insurance. In that case insurers are often forced by regulation to provide the coverage and refusal to insure is no longer an option.

Declining to renew a policy is another form of refusal to insure and can be equally effective. After the insured has conducted risky activities or failed to take mitigation measures, the insurers can cancel, rescind, or refuse to renew the existing policy. ${ }^{80}$ The threat of non-renewal could push homeowners to undertake mitigations.

${ }^{78}$ Howard Kunreuther, Has the Time Come for Comprehensive Natural Disaster Insurance?, in ON RISK AND DISASTER: LESSONS FROM HURRICANE KATRINA 175, 197 (Ronald J. Daniels et al. eds., 2006).

79 See infra Part IV, Section C.

${ }^{80}$ Ben-Shahar \& Logue, supra note 4, at 209. 
IV. REGULATION BY CATASTROPHE INSURANCE: EXAMPLES

The regulatory techniques of the insurance industry identified in the last section are already put into effect in various countries. This section will review specific types of catastrophe insurance in five jurisdictions. We first address private flood insurance in the U.K. This was, until recently, considered as one of only a handful of successful cases of catastrophe insurance in the world. The second case relates to the National Flood Insurance Program ("NFIP") in the U.S., a system which has been seriously criticized in the literature for providing inadequate incentives for prevention. The third system is the Catastrophes Naturelles ("Cat.Nat") insurance system in France. This provides an interesting model of a mandatory add-on for catastrophe risks, complementary to voluntary housing insurance. Such a model has been followed by many other countries in the world. The fourth system we address is the regulation through the Japanese Earthquake Reinsurance Scheme ("JER"). This scheme is remarkable as it is voluntary for policyholders, but mandatory for insurers. The fifth example constitutes the Turkish Catastrophe Insurance Pool ("TCIP"). This is "considered as a good example of catastrophe risk insurance for developing and middle-income countries". ${ }^{81}$

As these examples will demonstrate, there is wide variation in the nature and extent of regulation through catastrophe insurance across different countries. For each country we will first sketch the availability of catastrophe insurance and whether there is influence projected through public regulation. Subsequent, we will examine to what extent the technical tools we discussed in the previous section (risk-based pricing, contract design, loss prevention, claim management or refusal to insure) can and are used in practice.

81 EugEne GuRENKO ET AL., THE WORLd BANK, EARTHQUAKE INSURANCE IN TURKEY: HISTORY OF THE TURKISH CATASTROPHE INSURANCE POOL, xiv (2006). 


\section{A. UNITED KINGDOM}

In the United Kingdom, natural catastrophe risk coverage is included among the basic guarantees in commercial and household policies. Many households, for example, are in effect covered against flood damage, which is usually included in homeowners' insurance policies because mortgage lenders require that a property have full insurance coverage. ${ }^{82}$ The flood insurance scheme emerged in 1961. ${ }^{83}$ According to a gentlemen's agreement ${ }^{84}$ that divided the rights and duties between the State and the insurance industry, insurers regulate policyholders and compensate victims in the case of flood damage, while the State sets rules and codes for flood protection, flood warning and land use, and guarantees the independence of insurers' operation. ${ }^{85}$ The distinguishing feature of the U.K.'s catastrophe insurance scheme was that the State did not intervene in either direct insurance or reinsurance. This UK model was based on a close collaboration between the state and private insurers whereby the private insurers agreed to generously provide insurance coverage and the state committed to invest in flood protection prevention measures. For a long time this UK private flood insurance scheme was considered as a model, showing how a largely private insurance could work in an efficient and sustainable manner. ${ }^{86}$ However, recent large floods have fundamentally challenged these mechanisms as it was held (by insurers and by the public opinion) that the state did not sufficiently invest in flood protection

82 Erwann Michel-Kerjan, Catastrophe Economics: The National Flood Insurance Program, 24 J. OF ECON. PERSPECTIVES 165, 183 (2010).

${ }^{83}$ Michael Huber, Insurability and Regulatory Reform: Is the English Flood Insurance Regime Able to Adopts to Climate Change?, 29 GENEVA PAPER ON RISK AND INS. ISSUES AND PRAC. 169, 172 (2004).

84 According to a gentlemen's agreement between the British government and private insurers, the insurers undertook to offer flood coverage to owners of houses and organizations. See Michael Huber, Reforming the UK Flood Insurance Regime: The Breakdown of a Gentlemen's Agreement, in 18 CARR DISCUSSION PAPERS 1, 4 (Centre for Analysis of Risk and Regulation, 2014).

${ }_{85}^{85}$ Huber, supra note 83, at 172.

${ }^{86}$ Id. at $174-75$. 
measures and therefore was not meeting its part of the deal. These recent developments fundamentally challenged the stability of the system as insurers have even threatened cancelling the gentlemen's agreement. ${ }^{87}$

In 2013, the State and the insurance industry agreed to a Memorandum of Understanding known as Flood Re. ${ }^{88}$ Flood Re, finds its basis in the U.K. Government Water Act of 2014. Flood Re, a not-for-profit reinsurance fund owned and managed by private insurers, is designed to ensure regulation by flood insurance and keep it widely available and affordable. It is estimated that 300,000-500,000 high flood-risk households would struggle to obtain affordable flood insurance without Flood Re. ${ }^{89}$ The Water Act of 2014 was launched on April 4, 2016. It contains detailed provisions related to the structure and working of the flood insurance scheme. Primary insurers sell a homeowners' insurance policy with flood coverage to households in the usual way and then pass the flood risk to Flood Re, which pays the insurers if flood claims are made..$^{90}$ The scheme ensures regulation by flood insurance because the claim still rests with the primary insurers, but are backed up by Flood Re. The Flood Re fund has two sources of income: one is the flood element premium of the home insurance policies, and the other is an additional levy on the insurance industry. ${ }^{91}$ However, in an extreme situation — for example, a year with

${ }_{88}^{87}$ Hjalmarsson \& Bek, supra note 46, at 197.

${ }^{88}$ The Flood Re model is loosely based on Pool Re, a reinsurance scheme for terrorism risks formed in 1993 in response to the threat posed by the Irish Republican Army and other terrorist activity. See id.

${ }^{89}$ The Future of Flood Insurance: What Happens Next?, Association OF BRITISH INSURERS (2015), https://www.abi.org.uk/Insurance-andsavings/Topics-and-issues/Flooding/Government-and-insurance-industry-f lood-agreement/The-future-of-flood-insurance.

90 Flood Re Explained, AsSOCIATION OF BRITISH INSURERS (2015), https://www.abi.org.uk/products-and-issues/topics-and-issues/flood-re/flo od-re-explained/.

${ }_{91}$ Government and Insurance Industry Flood Agreement (Statement of Principles), ASSOCIATION OF BRITISH INSURERS (2014), https://www.abi.org.uk/Insurance-and-savings/Topics-and-issues/Flooding /Government-and-insurance-industry-flood-agreement. 
damage figures six times worse than 2007-the government will take primary responsibility, and work with both the insurers and Flood Re. ${ }^{92}$

Risk-Based Pricing. Initially, the premiums were undifferentiated across all households, and yet, as time went by, insurers improved their knowledge through accurate flood maps and took the real risks into account. This is important since premiums of flood insurance are risk-based, not flat, and are set on a case-by-case basis. ${ }^{93}$ In 2001, for example, heavy premiums were required for properties where flood claims had been previously made. ${ }^{94}$ Furthermore, for households located in flood-prone areas, premiums have increased significantly during the last few years. ${ }^{95}$

Insurers in the U.K. can, and prefer to, conduct risk-based pricing of flood insurance, because; 1) the State lacks control over the rate-setting as per the gentlemen's agreement; ${ }^{96}$ ) it helps control moral hazard, and "bad" risks are sorted out more rigorously; and, 3) it may provide incentives to policyholders to mitigate flood risks. ${ }^{97}$ Flood Re is also criticized since high risk houses will de facto be subsidized through a levy which will have to be paid by all domestic property owners. ${ }^{98}$

92 Id.

93 Michael Huber \& Tola Amodu, United Kingdom, in FINANCIAL COMPENSATION FOR VICTIMS OF CATASTROPHES: A COMPARATIVE LEGAL APPROACH 261, 291 (Michael Faure \& Ton Hartlief eds., 2006).

94 David Crichton, UK and Global Insurance Responses to Flood Hazard, 27 WATER INT'L 119, 122 (2002).

95 See Jessica E. Lamond et al., Accessibility of Flood Risk Insurance in the U.K.: Confusion, Competition and Complacency, 12 J. OF RISK RES. 825 (2009).

96 But the insurers also "agreed that the additional premium rate would not exceed 0.5 percent on the sum insured". See Crichton, supra note 94, at 127. What is more, according to the agreement between insurers and the government to develop the nonprofit company Flood Re, insurers will charge high-risk household a premium that will be capped depending on the property's Council Tax band. See ASSOCIATION OF BRITISH INSURERS, supra note 90.

97 Swenja Surminski, The Role of Flood Insurance in Reducing Direct Risk (2015), reprinted in FUTURE DIRECTIONS OF CONSUMER FLOOD INS. IN THE UK 15-25 (Johanna Hjalmarsson ed., 2015).

98 James Davey, Flood Re: Risk Classification and Distortion of the Market (2015), reprinted in FUTURE DIRECTIONS OF CONSUMER FLOOD INS. IN THE UK 20, 26 (Johanna Hjalmarsson ed., 2015). 
Contract Design. Deductibles are applied to some or all indemnification, depending on the type of damage and its cause. This follows the model provided by building insurance and content insurance, which cover not just ordinary perils like fire, but also earthquakes, floods and other catastrophe risks. ${ }^{99}$ Individual policy deductibles per $10^{5} \mathrm{IV}$ is $1 \%$ (between 78 and 156 on average, but could reach up to 2,333). ${ }^{100}$ Exclusions are also utilized in Flood Re, as homes built after January 1, 2009 , will not be covered if they would be constructed in known high flood-risk areas (as applied under the old Flood Insurance Statement of Principles). ${ }^{101}$ Such an arrangement offers real-estate developers the incentives to avoid construction in known high flood-risk areas.

Loss Prevention. Insurers promote loss prevention in a variety of ways. First, insurers actively engage with government regulation. In 2007, the Association of British Insurers ("ABI") demanded more government involvement in flood risk reduction, the approval of new compulsory building codes, and the development of long-term (twenty-five years) preventive strategy plans. ${ }^{102}$ Recently, the State has created the Planning Policy Statement ("PPS") 25 in collaboration with insurers, which proscribes land-use planning and flood damage reduction. ${ }^{103}$ Additionally, insurers conduct catastrophe risk research. At least twelve major insurers invest substantial sums in research aimed at producing more accurate flood maps. Although such research is expensive, these maps, which are better than the UK government or its agencies have been able to afford so far, will assist insurers to underwrite, and lead to more accurate pricing. ${ }^{104}$

99 WORLD FORUM OF CATASTROPHE PROGRAMMES, NATURAL CATASTROPHES INSURANCE COVER: A DIVERSITY OF SYSTEMS (2008).

100 The amounts for Individual policy deductibles per $10^{5} \mathrm{IV}$ and Premium levels are assessed on the basis of maximum damage (i.e., in case a house is completely destroyed). See Paudel, supra note 43, at 264.

${ }_{101}^{100}$ See ASSOCIATION OF BRITISH INSURERS, supra note 89.

102 Summer Floods 2007: Learning the Lessons, Association OF BRITISH INSURERS, Nov. 2007, at 6.

${ }^{103}$ Huber, supra note 83, at 173.

${ }^{104}$ Crichton, supra note 94, at 122. 
Claim Management. Under the private insurance scheme, claims are made via the insurance company, and are established in the individual insurance contract. Because data gathering is focused on claim histories, and experience rating is applied in risk-based pricing, claim management helps control moral hazard.

Refusal to Insure. Individuals and organizations have a de facto obligation to buy flood coverage if they would like to secure a mortgage, because all homeowners wishing to secure a mortgage must purchase flood insurance. ${ }^{105}$ If the properties lack insurance coverage, they may decrease in value to the point where they are no longer marketable. ${ }^{106}$ Such quasi-mandatory arrangement makes the insureds take more than normal precautions. Therefore, insurers' refusal to insure will all but control the insureds' activities, and thus they can use this power to induce less risky behavior. As mentioned above, a consequence of the gentlemen's agreement is that private insurers in principle undertake to offer flood coverage to owners of houses and organizations. ${ }^{107}$ That, however, does not imply an unconditional commitment to provide cover for any risk.

Furthermore, insurers may refuse to renew flood policies, and negotiate with the government to undertake stronger protection measures. Indeed, ABI once warned the government to take firmer action on flood defense; otherwise the insurance industry would not be able to provide flood coverage. ${ }^{108}$ This conflict between the government and the UK insurers has come to a head in recent years. Many floods occurred, and many claims were made on the insurers. The latter claimed that the large losses due to the floods were related to the lacking investments by the government in flood prevention. Insurers therefore held that the UK government did not comply with its obligations under the gentlemen's agreement (to invest in public facilities aiming at flood prevention). Due to this, insurers therefore desired to cancel the gentlemen's agreement. If

\footnotetext{
105 Huber, supra note 83, at 6.

106 Huber, supra note 84, at 180.

107 Huber, supra note 83.

${ }^{108}$ Crichton, supra note 94, at 129.
} 
insurers are entitled to withdraw from the market, the problems of catastrophe risk will eventually be left for the State and society to resolve.

\section{B. The UNITED StATES}

The United States is often seen as an insurance-based society, whereby there are strong interdependencies between the government and the insurance industry. ${ }^{109}$ This government involvement can also be observed in the coverage of catastrophe risk. In that respect, three distinct models of collaboration between the government and the insurance sector can be distinguished. ${ }^{110}$ In a first model, private insurers are the principal guarantors against risk, and the government has only limited involvement. The Price-Anderson Act, concerning nuclear facilities, is an example of this model. ${ }^{111}$ Under this model, the Price-Anderson Act mandated the purchase of insurance but since 1975 there is no longer government involvement in the compensation. A first layer is paid by the liability insurer of the operator where the accident occurred; the second layer is provided through a collective payment by all nuclear operators active in the market through retroactive premiums collected by the Nuclear Regulatory Commission ("NRC"). The NRC manages the collection of the retrospective premiums, but the financial risk is born by the nuclear operators. ${ }^{112}$ In a second model, insurers provide the primary coverage for the risk while the State supplies the reinsurance coverage. The Federal

109 Baker \& Farrish, supra note 26, at 292.

110 See generally Robert L. Rabin \& Suzanne A. Bratis, United States, in Financial Compensation for Victims of Catastrophe: A Comparative Legal Approach 324 (M. Faure \& T. Hartlief eds. 2006).

111 See 42 U.S.C. 2210 (1988 \& Supp. 1992). "Today, the individual liability of a nuclear operator is $\$ 375$ million supplemented with a second layer of retrospective premiums of $\$ 11.86$ billion, leading to a total amount of $\$ 12.2$ billion without any government intervention." See Liu Jing \& Michael Faure, Compensating Nuclear Damage in China, 11 WASH. U. GLOBAL STUD. L. REV. 781, 813(2012).

112 Michael Faure \&Tom Vanden Borre, Compensating Nuclear Damage: A Comparative Economic Analysis of the U.S. and International Liability Schemes, 33 WM. \& MARY ENVTL. L. \& POL'Y REV. 219, 240-247 (2008). 
Terrorism Risk Program illustrates this model. ${ }^{113}$ In the third model, insurers do not assume risks, but only administer policy coverage for government agencies. Earthquake insurance in California ("California Earthquake Agency") ${ }^{114}$ and the National Flood Insurance Program ("NFIP") follow this model. ${ }^{115}$ This section will focus on the third model of natural catastrophe risks.

The United States is vulnerable to numerous types of natural catastrophes, and the risk of loss is increasing significantly. ${ }^{116}$ Standard homeowners and commercial insurance policies normally cover non-catastrophe damage, such as fire, wind, hail, and lightning; however, flood damage resulting from rising water and earthquakes (in California) is normally explicitly excluded from coverage. ${ }^{117}$ Flood insurance was first offered by private insurers in the late 1890s, yet the financial loss was too large for insurers, and they left the market. ${ }^{118}$ The NFIP, administrated by

113 See Bruggeman, Faure \& Heldt, supra note 47 at 230-231.

114 The California Earthquake Authority (CEA) is a state-run privately funded earthquake insurance program. Earthquake insurance can be purchased for an additional premium in all states except California, where today one normally buys an earthquake policy for residential damage through the CEA. Id. at 224-225.

115 VÉRONIQUE BRUGGEMAN, COMPENSATING CATASTROPHE VICTIMS: A COMPARATIVE LAW AND ECONOMICS APPROACH 415-432 (2010).

116 U.S. GOVERNMENT ACCOUNTABILITY OFFICE, Catastrophe Insurance Risk: The Role of Risk-linked Securities and Factors Affecting Their Use 8-11 GAO-02-941 (2002). According to the Federal Emergency Management Agency (FEMA), an event where related federal costs reach or exceed $\$ 500$ million is deemed as "catastrophe." See U.S. GOVERNMENT ACCOUNTABILITY OFFICE, Experiences from Past Disasters Offer Insights for Effective Collaboration after Catastrophe Events 2 GAO-09-811 (2009). See also Michel-Kerjan, Erwann, Jeffrey Czajkowski, and Howard Kunreuther, Could Flood Insurance be Privatized in the United States? A Primer, 40 THE GENEVA PAPERS ON RISK \& INS.-ISSUES \& PRAC. 179-208 (2015).

117 Seema Patel \& Sarala Nagala, Public Policy Considerations of Water

Damage Exclusions in Hurricane Insurance Policies, 17-27, https://www.law.berkeley.edu/library/resources/disasters/Patel_Nagala.pdf.

118 Howard KunReuther \& Richard J. ROTH, SR., PAYING THE

PRICE: THE STATUS AND ROLE OF INSURANCE AGAINST NATURAL DISASTERS IN THE UNITED STATES 40(1998). 
the Federal Emergency Management Agency ("FEMA"), was established according to the National Flood Insurance Act of 1968, in order to assume the flood risk and offer coverage. ${ }^{119}$ The Standard Flood Insurance Policy of the NFIP covers direct physical losses to structures and their contents caused by flood. ${ }^{120}$ The NFIP has sold more than 5.2 million policies in 22,000 communities over the past 40 years, and provided almost $\$ 1.3$ trillion in coverage. ${ }^{121}$ Most of these policies are for single-family, residential properties - such as those found in Florida - which comprise nearly $40 \%$ of the NFIP (in number of policies, premiums and coverage). ${ }^{122}$ However, due to homeowners' underestimation of the likelihood of flood damages, the penetration rate of flood insurance is not very high. For example, only $20 \%$ of those who suffered damage from Hurricane Sandy had purchased NFIP policies. ${ }^{123}$

FEMA, in administrating the NFIP, works in conjunction with private insurance companies through the Write Your Own ("WYO") program, which allows private insurers to issue policies in their own name, to adjust flood claims, and to defend, settle or pay all claims arising from the flood policies. ${ }^{124}$ Moreover, there is no reinsurance arrangement in the NFIP, and if claims exceed its financial capacity, the federal government provides a bailout. For example, after Hurricane Katrina, the NFIP required a bailout from the U.S. Treasury of close to $\$ 20$ billion. ${ }^{125}$ Through these cooperative efforts by the insurance industry and the government — where

119 But some private insurers still offer excess flood protection that provides higher limits of coverage than the NFIP. See Well, B. Excess Flood Market Steps up When National Flood Program Falls Short, INSURANCE JOURNAL (24 Jul. 2006).

${ }^{120}$ Rabin \& Bratis, supra note 110.

${ }^{121}$ Kunreuther, supra note 35.

122 Erwann Michel-Kerjan \& Kousky, C. Come Rain or Shine: Evidence on Flood Insurance Purchases in Florida, 77 J. OF RISK \& INS. 369-397 (2010).

${ }^{123}$ Christopher C. French, Insuring Floods: The Most Common and Devastating Natural Catastrophes in America, 60 VILL. L. REV. 53 (2015).

${ }^{124}$ Véronique Bruggeman, COMPENSATING CATASTROPHE VICTIMS: A COMPARATIVE LAW AND ECONOMICS APPROACH 420 (2010); Rabin \& Bratis, supra note 110.

125 JAFFEE, supra note 73. 
private insurers make use of their marketing channels, risk management expertise, and existing policy base, and the federal government works as the ultimate risk taker-the NFIP enables homeowners to purchase flood insurance.

Risk-Based Pricing. Premium setting in the NFIP is partially risk-based. At the very beginning, the NFIP tried to adopt risk-based premiums that differ per flood zone, but this proved to be difficult in practice. Because the owners of buildings built before the creation of the NFIP are reluctant to purchase policies providing higher coverage (and of course having higher premiums), premiums are determined by applying the Actuarial Rate Formula. The NFIP's overall pricing strategy, however, leads to important divergences from the true risk for a number of residents covered by the program. ${ }^{126}$ In 2012, the Biggert-Waters Flood Insurance Reform Act allowed insurers to eliminate certain premium subsidies and increase the risk-based pricing. However, in 2014, this was prohibited by the Homeowner Flood Insurance Affordability Act, which restored grandfathering and limited certain rate increases.

According to the calculation of Michel-Kerjan et al., around a quarter of the total NFIP policies are subsidized today. ${ }^{127}$ Subsidized premiums obviously do not reflect the accurate flood risk and represent on average only $35 \%-50 \%$ of the actual risk. ${ }^{128}$ Moreover, subsidized structures are generally more prone to flooding, and are thus riskier than other risk-based premiums structures. ${ }^{129}$

Contract Design. The NFIP provides deductibles, ranging between $\$ 500$ and $\$ 5000$. Although a higher deductible lowers the premium and encourages more mitigation measures, "97 percent of NFIP policy-holders

${ }^{126}$ See Michel-Kerjan, Czajkowski \& Kunreuther, supra note 116.

127 Id.

128 U.S. GOV'T ACCOUNTABILITY OFF., GAO-08-118T, FEDERAL EMERGENCY MANAGEMENT AGENCY: ON-GOING CHALLENGES FACING THE NATIONAL FLOOD INSURANCE PROGRAM (2007).

129 U.S. GOV'T ACCOUNTABILITY OFF., GAO-14-127, FLOOD INSURANCE: STRATEGIES FOR INCREASING PRIVATE SECTOR INVOLVEMENT (2014). 
choose deductible levels of $\$ 1000$ or less". ${ }^{130}$ The NFIP also uses coverage limits. For example, a single-family dwelling is normally eligible for up to $\$ 250,000$ in building coverage and up to $\$ 100,000$ in personal property coverage. $^{131}$

Loss Prevention. The National Flood Insurance Reform Act of 1994 creates mitigation insurance and develops a mitigation assistance program for the NFIP. The NFIP integrates risk mitigation and prevention measures, and it administers different kinds of mitigation programs. For example, the NFIP tries to supply premium discounts to encourage mitigation of risk. It operates the Community Rating System ("CRS"), which rewards communities that undertake mitigating activities with premiums discounts. ${ }^{132}$

Although the NFIP successfully reduced the vulnerability of new buildings to floods, it had less impact on existing buildings and was also not able to limit the development of flood-prone areas. ${ }^{133}$ The increasing federal disaster relief, moreover, may reduce an individual's incentive to prevent loss and contribute to this result. ${ }^{134}$ There has been substantial criticism on the payments made after Katrina arguing that they would encourage people to rebuild in vulnerable areas. ${ }^{135}$ Some hold that the NFIP

${ }^{130}$ Michel-Kerjan \& Kousky, supra note 122.

131 Rabin \& Bratis, supra note 110, at 332.

132 See Hudson et al., supra note 38.

133 Raymond J. Burby, Rising Tide: The Great Mississippi Flood of 1927 and How It Changed America, 66 J. AM. PLAN. ASs'N 337 (2000) (book review).

134 The number of Presidential disaster declarations has significantly increased over the past 50 years: namely, from 162 over the period 1955-1965 to 545 during 1996-2005. In response to Hurricane Katrina in 2005 and in the subsequent year, three emergency supplemental appropriation bills of about $\$ 88.4$ billion were enacted by Congress. This total amount of federal relief is more than the combined total amounts of private wind insurance claims and NFIP claims. See Erwann Michel-Kerjan et al., Policy Tenure Under the U.S. National Flood Insurance Program (NFIP), 32 RISK ANALYSIS 644, 644-658 (2012).

135 William F. Shughart II, Katrinanomics: The Politics and Economics of Disaster Relief, 127 PUB. CHOICE 31, 44 (2006). 
therefore provides incentives for property development in high-risk areas. ${ }^{136}$

Claim Management. The NFIP uses insurers, because of their claims handling expertise, to settle claims on its behalf. Yet the NFIP bears further responsibility with regards to claim management, as the Flood Insurance Reform Act of 2004 stipulates that it should increase and improve guidance for policyholders about the flood insurance claims process and reduce the compensation to properties for which repetitive flood insurance claim payments have been made. However, anecdotal evidence suggests that because insurers do not assume underwriting risk in the NFIP, the claims costs are higher than they would be under a private insurance scheme. ${ }^{137}$

Refusal to Insure. This regulatory tool has little function in the NFIP. Since insurers do not assume underwriting risk and receive an expense allowance for policies written, they have no incentives to refuse to insure. Instead, the NFIP tries every effort to attract individuals to subscribe to the flood insurance policy. The Flood Disaster Protection Act of 1973 mandates that lenders require flood insurance on loans secured by properties that are located within high-risk flood areas. ${ }^{138}$ Moreover, the National Flood Insurance Reform Act of 1994 prevents federal agencies from granting disaster aid in the Special Flood Hazard Areas ("SFHAs") to communities that had not joined the NFIP. ${ }^{139}$

136 Justin Pidot, Deconstructing Disaster, 2013 BYU L. REV. 213 (2013); Andrew T. Young, Replacing Incomplete Markets with a Complete Mess: Katrina and the NFIP, 35 IN'L J. SOC. ECON. 561, 566 (2008).

${ }^{137}$ Because when the payment of claims exceeds their premium funds, they can collect FEMA letters of credit for any claim amount. See Crichton, supra note 94.

${ }_{138}$ Carolyn Kousky \& Erwann Michel-Kerjan, Examining Flood Insurance Claims in the United States: Six Key Findings, 84 J. RISK \& INS. 819-850 (2015). 99.

${ }^{139}$ See WORLD Forum of CATAStrophe Programmes, supra note 
C. FRANCE

In France, catastrophe risks, such as floods and earthquakes, were traditionally excluded from insurance coverage. However, after the 1981 floods in the Rhone, Saone and Garonne valleys, French legislators created the famous Act of July 13, 1982, which establishes the Catastrophes Naturelles System ("Cat.Nat"). ${ }^{140}$ This system offers a unique public-private partnership in regulating catastrophe risks. The division of responsibilities between the insurers and the State according to the Cat.Nat System compares well to some of the other systems discussed. The insurers are responsible for underwriting policies, managing additional premiums, adjusting damages, handling claims and paying indemnifications, while the State is responsible for reinsurance and cooperating with insurers to create prevention and mitigation plans. ${ }^{141}$ Article 1 of the Act of July 13, 1982 provides that property insurance policies that cover damage against property are automatically and mandatorily insured against the risk of natural disaster. ${ }^{142}$ Although natural catastrophe disasters are "the non-insurable direct material damage," they must be insured in the Cat.Nat System. ${ }^{143}$ This mandatory requirement, coupled with its efficient enforcement by the French authorities, brings the penetration rate of catastrophe insurance to nearly $100 \%{ }^{144}$ In addition, the State will back private insurers via reinsurance by the Caisse Centrale De Reassurance ("CCR") with unlimited State guarantee. ${ }^{145}$ This enables primary insurers

140 Act No. 82-600 of 13 July 1982 on the Indemnification of Victims of Natural Catastrophes, JORF 14 (1982).

${ }^{141}$ See Paudel, supra note 43, at 257-285.

142 See WORLD FORUM OF CATASTROPHE PROGRAMMES, supra note 99.

143 Article L. 125-1 Insurance Code: "Non insurable direct material damage the determining cause of which was the abnormal intensity of a natural agent, when normal measures taken to avoid such damage have been unable to prevent the occurrence thereof or could not be taken, shall be deemed to be a natural disaster within the meaning of this chapter."

${ }_{144}$ Michel-Kerjan, supra note 82.

145 See WORLD FORUM OF CATASTROPHE PROGRAMMES, supra note 99. 
to underwrite catastrophe insurance policies at affordable prices for homeowners.

Risk-Based Pricing. The Cat.Nat System adopts a flat rate rather than risk-based premiums. It is the government that fixes the premiums corresponding to the guarantee against the effects of natural catastrophes. Under the influence of the national solidarity principle, Article 2 of the Act of July 13, 1982 stipulates that "this guarantee is financed by an additional premium calculated on the basis of a single rate set by Decree for each category of insurance policy." This additional premium for catastrophe coverage is decided by the State in the form of a Ministerial Order, and applied to each type of basic policies. ${ }^{146}$ Originally the initial rate was $5.5 \%$ in 1982; it increased to $9 \%$ the following year and to $12 \%$ in $2000 .{ }^{147} \mathrm{As}$ this flat premium does not comply with the principle of risk-based pricing, it in principle creates few incentives for policyholders to reduce risk. Although the additional premium for the catastrophe coverage has been regulated by statutes, there could still be some competition between insurers. The competition would then not take place with respect to the Cat.Nat cover (as premiums have been regulated) but with respect to the basic premium for the housing insurance. Recall that the additional Cat.Nat cover (for which an additional fixed premium is asked) is linked as a complement to the voluntary housing insurance. If there were still competition between insurers as far as the premium for the basic housing insurance is concerned, insurers would have incentives for example to provide lower premiums to insured who would have invested in disaster risk reduction. Competition could thus stimulate investments in prevention. ${ }^{148}$ It is not so clear to what extent this really is the case; moreover, even if there were such a competition it is unclear whether there

146 Id at 64.

147 Michel CANNARSA, ET Al., France, in FinANCIAL COMPENSATION FOR VICTIMS OF CATASTROPHE: A COMPARATIVE LEGAL APPROACH 101 (M. Faure \& T. Hartlief eds. 2006).

${ }^{148}$ See generally Roger Van den Bergh \& Michael Faure, Compulsory Insurance of Loss to Property Caused by Natural Disasters: Competition or Solidarity? 29 World Competition 25 (2006). 
would be a reward for lower risks and hence a risk-differentiation. In 2006, the French public authorities presented a draft amendment to the 1982 Act, trying to abandon the unique extra insurance premium rate. ${ }^{149}$

Contract Design. There are mandatory and non-index-linked deductibles fixed in the Act. Originally, the amount of deductibles differed based on the type of risk-residential or commercial-but remained the same for all perils (except subsidence, which has a higher specific deductible). ${ }^{150}$ The Decree of August 10, 1982; September 7, 1983; September 19, 1983; and September 5, 2000, all insist on this rule. However, in order to control moral hazard and encourage loss prevention measures, a sliding scale has been introduced to vary these deductibles since January 1, 2001. ${ }^{151}$ Exclusions are also used in the Cat.Nat System, as the Act of July 13, 1982, stipulates that damage or costs indirectly due to the disaster event are not covered. ${ }^{152}$

Loss Prevention. The Cat.Nat System integrates risk mitigation and prevention measures. Insurers, moreover, cooperate with the State to formulate risk prevention plans and form the Barnier mitigation fund. ${ }^{153}$ The amount of the deductible also depends on whether a particular municipality has adopted a "prevention of risk plan" (plan de prevention des risques). This fact should hence incentivize the local population to press the municipality to adopt a prevention plan. ${ }^{154}$ However, recent empirical

${ }_{150}^{149}$ See WORLD FORUM OF CATASTROPHE PROGRAMMES, supra note 99. ${ }^{150} \mathrm{Id}$.

151 A sliding scale deductible means that if a state of natural catastrophe was declared in the area three times in the previous five years for the same sort of risk (such as floods), deductibles are doubled; if four times, they are trebled, and from five times on, the deductibles are multiplied by four. This deductible increase happens when the loss occurs in municipalities without a Foreseeable Natural Risks Prevention Plan. See BRUGGEMAN, supra note 115, at 307; WORLD FORUM OF CATASTROPHE PROGRAMMES, supra note 99 , at 65 .

64.

152 World ForUM OF CATASTROPHE ProgRAMMES, supra note 99, at

153 Paudel, supra note 141.

154 OLIVER MORÉTEAU, Policing the Compensation of Victims of Catastrophes: Combining Solidarity, Self-Responsibility, in SHIFTS IN 
evidence shows that this system does not provide optimal incentives for flood damage reduction. The deductibles' adjustment policy does not seem to provide incentives to communities to adopt a risk prevention plan in practice. ${ }^{155}$

Claim Management. The Insurance Code specifies the legal procedure of claim management. After government authorities declare a "natural catastrophe" in the official gazette, the insureds must report their damage to the insurers within ten days, with all relevant documentation including a statement of all direct damage to property (indirect damages are excluded), photos, videos etc. ${ }^{156}$ The timeframe of claim reporting is very strict (except when suspended by force majeure), and non-compliance may exclude the right to compensation. ${ }^{157}$ Setting a strict timeframe will press the policyholders to act with due care and diligence after the catastrophe, and allow insurers to send adjusters as soon as possible.

Refusal to Insure. Although the premiums are not risk-based, insurers may not refuse to underwrite individuals' catastrophe risk. When insurers undertake the higher risk, they can reduce risk by purchasing the relatively cheap reinsurance policies from the $\mathrm{CCR}$, the only reinsurer with an unlimited State guarantee. ${ }^{158}$

Compensation Between Private and Public Systems 199-218, 217 (Van Boom WH \& Faure M eds., 2007).

155 "In terms of financing damage mitigation measures, since 2005, the Fund for the Prevention of Major Natural Risks, also called the 'Barnier' fund, has been providing subsidies up to $€ 125$ million per year for studies on assessments of natural disaster risk and potential prevention and protection measures for buildings.” See Jennifer K. Poussin et al., Flood Damage Mitigation through Insurance: an Assessment of the French CatNat System, 12 ENVTL. HAZARDS 258-277 (2013).

156 Article L. 125 Insurance Code.

157 See World FORUM OF CATASTROPHE PROGRAMMES, supra note 99.

${ }^{158}$ Id. at $101-103$. 
D. JAPAN

The current Japanese earthquake insurance system is a public-private partnership between the government and the insurance industry. The system is divided into two different regimes, one for business and industry and the other for households. ${ }^{159}$ Business and industrial risks are covered primarily by the private insurance market, while household risks are covered by private insurers, but with strong government involvement. ${ }^{160}$

The household earthquake insurance regime is based on the Earthquake Insurance Act enacted in 1966, and offers coverage for not only earthquake, but also tsunami and volcanic eruption perils. ${ }^{161}$ Insurers who enroll in this scheme can offer direct coverage for earthquake damage as an extension of the optional property and casualty insurance policy. Individuals may choose to purchase earthquake insurance, yet it is mandatory for insurers to supply it. The primary insurers cede $100 \%$ of the underwritten earthquake insurance exposure to the Japanese Earthquake Reinsurance Scheme ("JER"). ${ }^{162}$ Established by the Japanese government, the JER is responsible for reinsurance of household earthquake insurance through a state guarantee. ${ }^{163}$ In other words, the Japanese government works as a de facto reinsurer, because after primary insurers pay claims of earthquake losses, they will be compensated by the government through the JER. ${ }^{164}$

Because it is not mandatory for homeowners to purchase earthquake insurance, its penetration ratio is not very high. For example, the

159 See generally Michael Faure \& Liu Jing, The Tsunami of March 2011 and the Subsequent Nuclear Incident at Fukushima: Who Compensates the Victims, 37 Wm. \& Mary Envtl. L. \& Pol'y Rev. 129 (2012).

${ }^{160}$ WORLD FORUM OF CATASTROPHE PROGRAMMES, supra note 99, at 86-90 (2008).

161 The Geneva Association, Insurers' Contributions to Disaster Reduction-A Series of Case Studies (2013) at 47.

162 Id. at 48.

163 Paudel, supra note 141.

164 The Geneva Association, supra note 161, at 48. 
1995 earthquake revealed a 9\% penetration ratio. However, this figure has increased to $23.7 \%$ following the 2011 Tohoku earthquake. ${ }^{165}$

Risk-Based Pricing. According to the Law Concerning Earthquake Insurance, earthquake insurance applies risk-based premiums. Japan is divided into seven risk zones, and insurers set premiums based on the degree of exposure and building types. Earthquake policy premiums covering industrial risks and other non-household risks, for example, have normally been applied on an individual basis, depending on the basic estimate for the building structure (five types) and the location according to the degree of exposure (seven levels), ranging from 1.1 per thousand (minimum risk: class A building, level 1 location) to 18.6 per thousand (maximum risk: class E building, level 7 location). ${ }^{166}$ Household earthquake insurance premiums are also determined in relation to two additional factors: the location of the property, and the type of construction. ${ }^{167}$

This system of premium differentiation is sometimes criticized as insufficient. For example, the division of zones has been criticized as extremely rough and crude, and the significant variation in earthquake risk between classes is not sufficiently reflected in the premium rating. ${ }^{168}$

Besides the earthquake insurance established by the Law Concerning Earthquake Insurance, cooperative insurers known as Kyosai provide the bulk of household coverage, including earthquake coverage. However, premiums provided by Kyosai do not vary by location and are less likely to incentivize mitigation measures by policyholders. ${ }^{169}$

165 Id. at 49.

166 WORLD FORUM OF CATASTROPHE PROGRAMMES, supra note 99, at 165.

${ }^{167}$ But the degree to exposures of location is only four levels, and the type of building structure is only divided into wood or reinforced. See WORLD FORUM OF CATASTROPHE PROGRAMMES, supra note 99, at 93.

168 Michio Naoi et al., Community Rating, Cross Subsidies and Underinsurance: Why So Many Households in Japan do not Purchase Earthquake Insurance, 40 J. REAL ESTATE FIN. ECON. 544, 560 (2010).

${ }^{169}$ Faure \& Jing, supra note 159, at 147, 161. 
Contract Design. The JER makes use of deductibles. If the premium exceeds $\$ 550$ per policy, this amount is the deductible. Otherwise, the deductible is equal to the premium of the policy. A maximum limit is also imposed: the total maximum limit for compensation by all insurers and government is $\$ 55.7$ billion per earthquake. ${ }^{170}$

Loss Prevention. Under the JER regime, more loss prevention is conducted by the government than by insurers. This is because the government controls large-scale construction and development projects in different seismic risk-zones and the coverage and market penetration of earthquake insurance is not very high - about $20 \%$ before the devastating 2011 earthquake - so it follows that the insurers have fewer incentives to supply loss prevention services. ${ }^{171}$

Claim Management. Under the JER, claims are made via the insurance company, and are established in the individual insurance contract. ${ }^{172}$

Refusal to Insure. Household earthquake insurers may not refuse to insure; the insured may choose whether to accept it or not, but the insurers must provide it. Furthermore, the primary insurers can cede all risks against earthquakes for reinsurance to the JER (Earthquake Reinsurance Treaty "A"). The government will assume the ultimate risk.

For earthquake insurance covering business and industrial risks, insurers make exact assessments of the risks, and are very restrictive in terms, conditions, and ceilings. However, the supply of earthquake insurance is quite sufficient, and policyholders can choose from a large variety of options, including private insurers, the Kyosai, and in some cases local mutual funds. ${ }^{173}$ This regulatory tool, therefore, has limited applicability in Japan.

${ }^{170}$ Paudel, supra note 43, at 277.

${ }^{171}$ Kuang-Yin Lai et al., The 2005 Ilan earthquake doublet and seismic crisis in northeastern Taiwan: evidence for dyke intrusion associated with on-land propagation of the Okinawa Trough, 179 GEOPHYSICAL J. INT'L 678 (2009).

172 See Faure \& Jing, supra note 159.

173 Faure \& Jing, supra note 159, at 148-50. 
E. TURKEY

Turkey is a land plagued with earthquakes, which cause two thirds of all natural catastrophe damages. ${ }^{174}$ An important attempt to address this problem is the establishment of the Turkish Compulsory Insurance Pool ("TCIP"). ${ }^{175}$ In 1999, Governmental Decree Law No. 587 on Compulsory Earthquake Insurance ("Decree Law") came into force and gave birth to the TCIP. One of the main objectives of the TCIP is to encourage risk reduction and to motivate the mitigation practices of households. ${ }^{176}$ As a market insurance mechanism, the TCIP supplies earthquake insurance to homeowners, and covers losses caused by earthquakes and earthquake-related catastrophes, such as fires, explosions, landslides, and tsunamis. ${ }^{177}$ The Disaster Insurance Law (Law No. 6305), which sets out the regulations of the compulsory earthquake insurance system in detail, aims to prevent fraudulent claims and to increase the participation rate. ${ }^{178}$ As of January 2015, the total number of policies issued was 6.8 million, the total premiums collected were $\$ 380$ million, the total paid claims were $\$ 80$ million, the total payment capacity was $\$ 6$ billion, and household participation rate stood at $38.9 \% .{ }^{179}$

The TCIP is a public entity, but has no public sector employees. It is administered by the TCIP Board of Directors, which consists of seven members drawn from government agencies, insurance companies, and the universities. The government appoints an insurance or reinsurance company as the pool management company to oversee the daily operations

${ }^{174}$ WORLD FORUM OF CATASTROPHE PROGRAMMES, supra note 99, at 163.

175 The TCIP was formed with the cooperation of the World Bank, the Turkish Government and the Insurance sector. See id. at 163-64.

${ }_{176}$ GURENKO ET AL., supra note 81, at xii.

${ }^{177}$ B. Burcak Başbuğg-Erkan \& Ozlem Yilmaz, Successes and failures of compulsory risk mitigation: re-evaluating the Turkish Catastrophe Insurance Pool, 39 DISASTERS 782, 785 (2015).

${ }^{178} I d$. at 790.

$179 \mathrm{Id}$. at 786 . 
of the TCIP. ${ }^{180}$ Insurance companies conduct all the business tasks of the TCIP, including underwriting, claim management, and reinsuring, but they do not assume any risk. Moreover, when the payments of claims exceed the capacity of TCIP, the State provides contingent liquidity support. ${ }^{181}$

Risk-Based Pricing. The TCIP adopts a differential risk-based pricing approach. According to Article 10 of the Decree Law, three factors are considered when determining the insurance premiums: location, construction type, and gross square area. ${ }^{182}$ The premiums are divided into fifteen tariff rates, according to the Turkey Seismic Zones Map, and into three different construction types. ${ }^{183}$ Consequently, risk-based pricing allows the TCIP to considerably reduce moral hazard and adverse selection. ${ }^{184}$

Contract Design. The TCIP provides a minimum 2\% deductible to the sum insured in order to avoid "penny claims". ${ }^{185}$ The TCIP, moreover, applies a maximum limit, and the sum for all construction type is NTL $110,000 .{ }^{186}$ In addition, there are exclusions in the TCIP policies. For example, earthquake damage is excluded if the building was constructed after December 27, 1999, but without any valid construction license. ${ }^{187}$ The TCIP also imposes construction maintenance obligations on the insured in the policies, as Article 14 stipulates:

180 WORLD FORUM OF CATASTROPHE PROGRAMMES, supra note 99, at 165.

${ }^{181}$ GURENKO ET AL., supra note 81, at xi.

182 Id. at 92. (citing an English Translation of Turkish Governmental Decree Law No. 587 on Compulsory Earthquake Insurance as published in the Official Gazette No. 23919, Dec. 27, 1999) ("In determining the insurance premiums, the following factors are taken into account: square meter of the building, construction category and quality, geological characteristics of the plot of land on which the building is erected, earthquake risk, and similar factors.")

${ }^{183} I d$. at 53 .

${ }^{184}$ Id. at 35 .

${ }^{185} \mathrm{Id}$. at 32-33.

186 WORLD FORUM OF CATASTROPHE PROGRAMMES, supra, note 99, at 168.

${ }^{187}$ See GURENKO ET AL., supra note 81, at 51. 
The owner who causes or allows the building and each independent section thereof to be altered contrary to the related design and in a way that will affect the load-bearing system, loses his entitlement to compensation in as much as the actual loss arises or increases because of such reason. ${ }^{188}$

Loss Prevention. The TCIP was initiated as a loss prevention mechanism. It has played an important role in enhancing and monitoring the current National Building Code in Turkey ${ }^{189}$ and has also implemented revisions in land use planning and other mitigation plans. ${ }^{190}$ In addition, the TCIP pays much attention to education intended to raise public awareness to catastrophe risk. For example, the TCIP endeavors to introduce the concept of earthquake risk management and insurance in school textbooks. ${ }^{191}$

Claim Management. Homeowners whose houses were damaged as a result of earthquakes, and those who have a Compulsory Earthquake Insurance Policy, should consult TCIP or the insurance companies, or both, within fifteen working days of becoming aware of any damage. ${ }^{192}$ Meanwhile, loss adjustment is one of the most critical issues in the whole operation of the TCIP system due to its role in managing moral hazard of policyholders. The TCIP retains loss adjusters already employed in the property insurance companies. ${ }^{193}$

Refusal to Insure. The TCIP can refuse to insure buildings without valid construction license or occupancy permits. It may also cancel the policy if the insureds make alterations to the building contrary to legislation within the insurance period. ${ }^{194}$ The refusal or cancellation of coverage

188 English translation of Governmental Decree Law No. 587 on Compulsory Earthquake Insurance as published in Official Gazette No. 23919, Article 14 (December 27, 1999).

${ }^{189}$ Başbuğ-Erkan \& Yilmaz, supra, note 177, at 784.

190 See Paudel, supra note 43, at 278.

191 GURENKO ET AL., supra note 81, at xiii.

${ }^{192} \mathrm{Id}$. at 59.

${ }^{193}$ GURENKO ET AL., supra note 81, at 58.

${ }^{194}$ Id. at 59 . 
provides incentives for homeowners or builders to comply with construction codes, because homeowners who want to register any real-estate transaction, or open accounts for water and natural gas services, must present a valid earthquake insurance policy. ${ }^{195}$

\section{COMPARATIVE DISCUSSION}

Controlling moral hazard and providing incentives to mitigate losses benefit both policyholders and insurers. Such efforts decrease both risk and cost for policyholders, therefore enhancing profits and financial solvency for insurers. In the context of climate change, it is especially important to integrate incentives to risk mitigation in catastrophe insurance and thus promote climate change adaptation. ${ }^{196}$ The below table summarizes the overview of regulation by catastrophe insurance across the five countries that were explored in the previous section.

First, the question will be addressed to what extent the five technical tools aiming at disaster risk reduction are to a greater or lesser extent employed in the countries examined. Thereby the crucial question will also be asked to what extent this is encouraged or restricted as a result of public regulation. Second, a brief assessment of the effectiveness of disaster risk insurance in the five specific countries will be provided.

195 Id. at 24.

196 See W.J.W Botzen \& J.C.J.M. Van Den Bergh, Managing natural disaster risks in a changing climate, 8 ENVTL. HAZARDS 209 (2009). 
A. The Use of TeChNicAl ToOls

Table 1: Regulation by Catastrophe Insurance Comparative Table

\begin{tabular}{|c|c|c|c|c|c|}
\hline 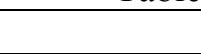 & UK & US & France & Japan & Turkey \\
\hline $\begin{array}{l}\text { Risk-based } \\
\text { Pricing }\end{array}$ & $\begin{array}{l}\text { Yes, and } \\
\text { individualized. } \\
\text { No longer under } \\
\text { Flood Re }\end{array}$ & $\begin{array}{l}\text { Partially, } 1 / 4 \\
\text { policies } \\
\text { subsidized }\end{array}$ & No, flat rate & $\begin{array}{l}\text { Yes, but for } \\
\text { Kyosai }+ \\
\text { criticized }\end{array}$ & $\begin{array}{l}\text { Yes. } \\
\text { The TCI pool } \\
\text { applies and } \\
\text { the law } \\
\text { provides the } \\
\text { context. }\end{array}$ \\
\hline $\begin{array}{l}\text { Contract } \\
\text { Design }\end{array}$ & $\begin{array}{l}\text { Yes. } \\
\text { Deductibles; a } \\
\text { given limit for } \\
\text { the whole } \\
\text { content } \\
\text { insurance. }\end{array}$ & $\begin{array}{l}\text { Yes. } \\
\text { Deductibles; } \\
\text { maximum } \\
\text { limit. }\end{array}$ & $\begin{array}{l}\text { Yes. } \\
\text { Deductibles; } \\
\text { exclusions; a } \\
\text { given limit for } \\
\text { the whole } \\
\text { property } \\
\text { insurance } \\
\text { policies. }\end{array}$ & $\begin{array}{l}\text { Yes. } \\
\text { Deductibles; } \\
\text { maximum } \\
\text { limit. }\end{array}$ & $\begin{array}{l}\text { Yes. } \\
\text { Deductibles; } \\
\text { maximum } \\
\text { limit; } \\
\text { exclusions; } \\
\text { insureds' } \\
\text { obligation. }\end{array}$ \\
\hline $\begin{array}{l}\text { Loss } \\
\text { Prevention }\end{array}$ & $\begin{array}{l}\text { Yes. } \\
\text { Engaging with } \\
\text { government } \\
\text { regulation; } \\
\text { conducting } \\
\text { catastrophe risk } \\
\text { research }\end{array}$ & $\begin{array}{l}\text { Yes. } \\
\text { Mitigation } \\
\text { assistance } \\
\text { programs; } \\
\text { risk-zoning } \\
\text { and risk maps; } \\
\text { building code } \\
\text { regulations. } \\
\text { NFIP } \\
\text { promotes } \\
\text { rebuilding in } \\
\text { high-risk } \\
\text { areas. } \\
\end{array}$ & $\begin{array}{l}\text { Yes. } \\
\text { Risk } \\
\text { prevention } \\
\text { plan; } \\
\text { mitigation } \\
\text { fund. }\end{array}$ & $\begin{array}{l}\text { Minimal. Low } \\
\text { penetration. }\end{array}$ & $\begin{array}{l}\text { Yes. } \\
\text { Education, } \\
\text { implementing } \\
\text { mitigation } \\
\text { measures. } \\
\text { Monitoring } \\
\text { via the } \\
\text { Building } \\
\text { Code. }\end{array}$ \\
\hline $\begin{array}{l}\text { Claim } \\
\text { Management }\end{array}$ & Yes. & $\begin{array}{l}\text { Yes, but costs } \\
\text { higher than } \\
\text { private } \\
\text { insurance } \\
\text { scheme. }\end{array}$ & $\begin{array}{l}\text { Yes. } \\
\text { Time limit. }\end{array}$ & Yes. & $\begin{array}{l}\text { Yes. } \\
\text { Time limit. }\end{array}$ \\
\hline $\begin{array}{l}\text { Refusal to } \\
\text { Insure }\end{array}$ & $\begin{array}{l}\text { Yes, and it works } \\
\text { well due to de } \\
\text { facto obligation } \\
\text { of homeowners. }\end{array}$ & No. & No. & $\begin{array}{l}\text { No for } \\
\text { household } \\
\text { earthquake } \\
\text { insurance. } \\
\text { Others yes. }\end{array}$ & $\begin{array}{l}\text { Yes. } \\
\text { It works well } \\
\text { combined } \\
\text { with } \\
\text { compulsory } \\
\text { insurance. }\end{array}$ \\
\hline
\end{tabular}


As Table 1 shows, all technical tools of private regulation are used to a greater or lesser extent in the countries examined. However, the effectiveness of these technical tools often depends upon the institutional setting, in other words on the public regulation. Consider for example the first and probably most important tool (notably to stimulate disaster risk reduction) being risk-based pricing. In the UK this was allowed and applied since the state refrained from intervention in premium setting as a result of the gentlemen's agreement. As indicated, this is no longer true under the new Flood Re model. In the United States, however, exactly the opposite is the case, where risk-based pricing is prohibited by the Homeowner Flood Insurance Affordability Act. As a result of this, the premiums charged are substantially less than the actual risk. In France, it is the government that sets the premium for the Cat.Nat coverage mandatorily by regulation, which excludes risk-based pricing. In Japan, it is again the law that determines the system of risk differentiation applied in earthquake insurance, which according to some is an ineffective tool to provide proper incentives for disaster risk reduction. Finally, in Turkey it is the law on compulsory earthquake insurance which created the TCIP that provides the context for risk-based pricing.

The same conclusion could be reached for the other technical tools that were examined. Generally, one can conclude that the ability of insurers to apply technical tools aiming at disaster risk reduction strongly depends upon the institutional context. For example, the refusal to insure may not be applied in some countries as it is simply prohibited by regulation. In the UK the refusal to insure is possible, again under the then existing gentlemen's agreement with the government. But in the US the refusal to insure is basically non-existent for the simple reason that it is not the insurers but the government that runs the risk under the NFIP. This seems to be the model towards which the UK is now heading with Flood Re as well. The same conclusion can be reached for France where the Cat.Nat coverage is mandatorily included for every individual who purchases (voluntary) housing insurance. Exclusion of bad risks is hence impossible as a result of the regulation. And the same conclusion can be reached for Japan. Note that 
in three countries (the US, France and Japan) there is no possibility to refuse the insurance and insurers are de facto able to transfer the consequences of bad risks to the government as in all three systems it is the government that either carries the risk (the US) or generously provides reinsurance (France and Japan). In those systems, compensation for hard to insure catastrophes is hence provided as a result of the government intervention, but at the same time one of the technical tools to stimulate disaster risk reduction by individuals (the refusal to insure) cannot be employed. The TCIP in Turkey is an exception where a refusal to insure is possible.

A conclusion from this brief overview is that the possibilities for insurers to actively provide incentives for disaster risk reduction and hence play a role as private risk regulators, strongly depends upon the institutional context and the nature of public regulation. It is often public regulation itself that prohibits the use of particular technical tools (such as premium differentiation). Of course, one has to be careful with drawing from this the policy conclusion that those interventions of public regulation jeopardize the development of technical tools aimed at disaster risk reduction by insurers. Of course, it may be the case that in those countries where public regulation limits the possibilities for insurers to apply tools aiming at disaster risk reduction, that other legal rules aim at reaching the same goal. More specifically the government itself could for example (via investments in public infrastructure) be very active in developing tools of risk reduction (such as improving the dikes or a levee system). The other alternative would be that the government imposes a duty on homeowners to invest in disaster risk reduction via regulation. If that hypothesis were true, the limitations imposed upon insurers by regulation to apply tools aiming at disaster risk reduction, would not be that problematic. The government could compensate for that weakness via investments in disaster risk reduction (via public infrastructure or regulation). However, there is little evidence of this. It is known that politicians generally underinvest in disaster precaution 
measures because of limited political pay-offs. ${ }^{197}$ There is also overwhelming evidence that the government systematically underinvests in disaster precaution as a result of this collective action problem ${ }^{198}$ and regulation directed at homeowners forcing them to take specific precautionary measures is equally rare; that is why, as was stated in the introduction, regulation by insurers is often presented as a remedy to failing public regulation. ${ }^{199}$ However, the above overview of the technical tools that would enable insurers to play this role shows that it is often public regulation that restricts the possibilities of private insurers to impose measures aimed at disaster risk reduction.

\section{B. COUNTRY COMPARISON}

In analyzing the way in which insurance systems described in the different countries provide incentives for disaster risk reduction one can come to several conclusions.

Until the beginning of this century the UK private flood insurance regime was considered a success story. Heavy floods after failing investments in flood protection by the government changed this picture. ${ }^{200}$ Relying on risk-based premiums and other regulatory techniques, flood insurers attempted to mitigate and control the moral hazard of households. Moreover, "bad risks" were identified and regulated more rigorously, and these houses became less marketable due to them lacking insurance coverage. In 2013, due in part to political pressure, the UK government and the insurers set up Flood Re to guarantee that high flood risk households could obtain affordable insurance. Insurers charge policyholders at a

197 See generally Ben Depoorter, Horizontal Political Externalities: The Supply and Demand of Disaster Management, 56 DUKE L.J. 101 (2006).

198 Giuseppe Dari-Mattiacci \& Michael Faure, The Economics of Disaster Relief, 37 L. \& POL'Y 180, 185 (2015).

${ }_{199}$ Ben-Shahar \& Logue, supra note 4, at 200.

200 See Huber \& Amodu, supra note 93, at 294. ("If certain risks are no longer insurable, but coverage is socially demanded, other solutions have to be established."). 
premium that will be capped depending on the property's Council Tax band, and they will pass into Flood Re those high flood-risk homes. ${ }^{201}$ With this new development the high-risk property owners will receive subsidized insurance coverage, paid by all domestic property owners who have insurance, thus effectively redistributing from low to high risks. ${ }^{202}$

The UK system is now effectively more along the line of the NFIP in the U.S. That system is subject to much stronger moral hazard, due to its partially risk-based premiums and less efficient claim management. It implicitly encourages people to live in flood hazard areas and undermines the private insurance market. ${ }^{203}$ It is doubtful whether the NFIP could assume the future risk and potential losses because of the large number of people living in the flood-prone areas, and the increase in climate-related extreme events. It is for that reason that the NFIP has been subject to a lot of criticism $^{204}$ and to proposals for reform. On the one hand it has been proposed to reform the NFIP towards a model where premiums charged would better reflect risk; ${ }^{205}$ on the other hand it is argued that the US should move to a comprehensive natural disaster insurance regime in line with the French Cat.Nat model. ${ }^{206}$

Although the Cat.Nat System of France adopts a flat rate in catastrophe policies in consideration of solidarity, it does provide some incentives to mitigation through deductibles, through the municipal loss prevention plans (although their effectiveness has recently been challenged), and through claims management. More importantly, such a mandatory comprehensive catastrophe insurance regime allows insurers to play a more active role in regulation of individuals' behaviors than in voluntary regimes. The French model is followed by other countries, such

201 See ASSOCIATION OF BRITISH INSURERS, supra note 90.

202 Davey, supra note 98.

${ }^{203}$ Crichton, supra note 94, at 124.

204 See, e.g., French, supra note 123, at 54 ("[M]ost homeowners remain uninsured for flood losses and the insurance that is available to cover losses is inadequate.").

${ }^{205}$ See Kerjan, Czajkowski \& Kunreuther, supra note 116.

${ }^{206}$ Kunreuther, supra note 78, at 186. 
as Belgium, where, since 2005, flooding, earthquakes and other natural disasters are mandatorily included in all fire insurance policies. ${ }^{207}$

Risk-based pricing (except for Kyosai) is undoubtedly a positive aspect of the JER and induces policyholders to take mitigation measures. However, the insurers' role is limited because of the low penetration rate $(20 \%-25 \%)$ of earthquake insurance for households. Given Japan's vulnerability to serious earthquakes, there seems to be a strong argument in favor of mandatory earthquake coverage, similar to the French model.

Besides its role in developed countries, catastrophe insurance becomes an increasingly important form of regulation beyond the State in many developing countries. The application of the above regulatory tools in the TCIP affirms Turkey's image as a good example and a model solution for developing and middle-income countries. ${ }^{208}$

\section{EXPANDING THE ROLE OF REGULATION BY CATASTROPHE INSURANCE IN CHINA}

\section{A. Regulation By CATASTROPHE INSURANCE IN CHINA}

The current mechanism for managing catastrophe risks in China is known as the Whole-Nation System ("Juguotizhi"), which generally refers to the government's efforts to deploy and allocate the whole nation's resources to fulfill a specific and difficult task within a limited timeframe, and thus promote the nation's interest. ${ }^{209}$ Under the Whole-Nation System, the government is committed to restoring social and economic order after a disaster. However, such government aid easily causes moral hazard, and creates negative incentives to individuals who historically have a strong desire to rely on governmental bailout in the wake of a catastrophe. For

${ }^{207}$ BRUGGEMAN, supra note 115, at 496; Bruggeman, Faure \& Fiore, supra note 46 , at 371 .

${ }_{208}$ See generally GURENKO ET AL., supra note 81.

${ }^{209}$ Peijun Shi \& Xin Zhang, Chinese Mechanism against Catastrophe Risk-the Experience of Great Sichuan Earthquake, 28 J. TsINGHUA U. (PHIL. \& SOC. SCI.) 96, 111 (2013). 
example, some pure forms of government bailout, including ad hoc direct payment and compensation funds, provide insufficient incentives to risk prevention and loss mitigation. ${ }^{210}$

To some extent, more government bailouts may contribute to more disaster losses, because people are more likely to rely on the government to bail them out than to take precautionary measures. ${ }^{211}$ According to an empirical study on property and causality insurance in five Chinese provinces, there is a negative correlation between the amount of government relief and residents' investment in prevention measures, such as purchasing insurance. ${ }^{212}$ Many residents admit that they are exposed to catastrophe risks, but they seldom transfer risks through insurance because they believe that the government will bail them out when catastrophes happen. ${ }^{213}$

Homeowners insurance is one of the least developed lines in China, and its penetration rate is quite low. According to a survey using face-to-face interviews, only $4 \%$ of interviewees had bought homeowner insurance. ${ }^{214}$ However, the people's perception of catastrophe risk and acceptance of catastrophe insurance presents a more optimistic view. Most people would accept catastrophe insurance, while only $4 \%$ of respondents

${ }^{210} I d$. at $96-113$.

211 Tom Baker, On the Genealogy of Moral Hazard, 75 TEX. L. REV. 237, 238 (1996).

212 Tian Ling \& Zhang Yue, Influence Factors of Catastrophe Insurance Demand in China: Panel Analysis in a Case of Insurance Premium Income of Five Provinces, 26 J. WUHAN U. TECH. (SOC. SCI. ED.) 175-179 (2013).

213 HE WANG, RESEARCH ON CATASTROPHE RISK INSURANCE MECHANISMS 5 (2013).

214 The survey was conducted using face-to-face interviews with randomly selected respondents on trains and at railway stations in the summer of 2009. In total, 7,459 valid questionnaires were collected. The samples covered 856 different cities and counties and represented 36 percent of all cities and counties in China. See Ming Wang, et al., Are People Willing to Buy Natural Disaster Insurance in China? Risk Awareness, Insurance Acceptance, and Willingness to Pay, 32 RisK ANALYSIS 1717, 1721 (2012). 
considered catastrophe insurance to be unnecessary. ${ }^{215}$ The remainder of this section examines how catastrophe insurance might be used to supplement or even supplant the State governance through the Whole-Nation System. ${ }^{216}$ The possibility and feasibility of regulation by catastrophe insurance in China will be explored through the examination of its regulatory techniques.

Risk-Based Pricing. According to field research on Willingness to Pay ("WTP"), many people are willing to pay more premiums in order to acquire full coverage of property loss in catastrophe disasters. ${ }^{217}$ In setting these premiums, regional differences and construction types should be taken into account. As was discussed above, the U.K.'s flood insurance program has set up a good example of this scheme.

Urban and rural areas should receive different treatments in the proposed catastrophe insurance system, because income inequality has continued to rise since China's market-oriented reform. ${ }^{218}$ Homeowners in rural areas are low-income, and many of them could not afford insurance. China may learn from the TCIP, in which compulsory insurance for the dwellings built in rural areas is not anticipated, and the risk-based pricing is only applied on registered dwellings in urban areas. In fact, in the earthquake insurance pilot program in Chuxiong, the State decided to pay the cost of every rural community's insurance in order to guarantee coverage. $^{219}$

${ }^{215} I d$. at 1726 (" $34.7 \%$ and $39.8 \%$ of respondents believed that disaster insurance is very important and relatively important in all measures of disaster reduction and mitigation.") (21.5\% had no clear comment).

${ }^{216}$ It is still unknown, even for the pilot programs, how catastrophe insurance plays a role. No transaction information-such as risk-setting, insurance contract design, or claim management-is disclosed in the market.

${ }^{217}$ Interviewers aimed to obtain people's WTP based on their true beliefs and feelings, as any pre-assumed ranges of premium could have misled respondents' judgment. They therefore used open-ended questions to enquire about WTP. Id.

218 Martin King Whyte, Soaring Income Gaps: China in Comparative Perspective, 143 DAEDALUS 39 (2014).

219 Ling Tian, et al., Perception of Earthquake Risk: A Study of the Earthquake Insurance Pilot Area in China, 74 NAT. HAZARDS 1595 (2014). 
Contract Design. According to the field research, respondents who have poor house conditions tend to be more aware of earthquakes and have a stronger desire for insurance. ${ }^{220}$ High deductibles may induce people to live away from the hazard-prone areas and choose stronger building stlyes. When setting deductibles of policies, construction structure, house conditions, and locations should be important considerations. These tools of contract design are a common choice in the five catastrophe insurance programs discussed above.

Loss Prevention. According to the field research, $24.1 \%$ of respondents are not willing to purchase disaster home insurance because they know very little about insurance, and do not trust insurers. ${ }^{221}$ Education, therefore, should be emphasized in insurers' loss prevention services in order to create public awareness of the benefits of taking mitigation measures against catastrophe risks. In addition, if more people believe in the importance of insurance in addressing catastrophe risk, catastrophe insurance will reach a higher penetration rate, as there is a strong positive correlation between the two. ${ }^{222}$

Claim Management. Insurers in China do not perform loss adjustment and claim settlement well. According to the field research, 23\% of interviewees indicated that they do not trust insurers' claim management. Afraid of getting no payment after disasters, they are not willing to purchase catastrophe insurance. ${ }^{223}$ Insurers, therefore, should increase their transparency and efficiency in order to regain the public's trust.

Refusal to Insure. Concerted measures and policy are required in order for this regulatory technique to play a role in China. China could follow the examples of the TCIP. Specifically, the country should consider requiring homeowners who want to register any real-estate transaction, or open accounts for water and natural gas services, to present a valid earthquake insurance policy. Further, China should consider adopting the

\footnotetext{
${ }^{220} I d$.

221 See Wang, supra note 213, at 1727.

222 Id.

$223 I d$
} 
procedures of the NFIP, which stipulates that only through acquiring flood insurance for their homes, can homeowners in the 1/100 flood zone get home mortgage credits granted or secured by federal bodies or credit agencies.

In 1998, the People's Bank of China (i.e. the Chinese Central Bank) issued the Residential Mortgage Regulation, which states that before the mortgage contract is concluded, the mortgagor is required to obtain household insurance or to relegate this task to the mortgagee (Article 25). However, in 2006, the China Banking Regulatory Commission issued a notice forbidding banks from stipulating with mandatory effect that residential mortgage insurance must be acquired. ${ }^{224}$ Although acquiring household insurance is not related to mortgages, loans or other financial services, it is still beneficial to review the series regulations and explore the feasibility of such concerted measures to be used for the take-up of catastrophe insurance.

\section{B. EFFECTIVENESS OF REGULATION BY CATASTROPHE INSURERS}

There is little doubt that catastrophe insurers could influence the consumers' behavior. What is less clear is how effective is this influence. Theoretically speaking, both insurers and consumers present obstacles that may limit the effectiveness of regulation by catastrophe insurance. Catastrophe insurers may be reluctant to supply coverage for several reasons. First, insufficient catastrophe data impedes insurers' efforts to identify, quantify, and estimate the chances of disasters, and to set premiums for catastrophe risks. Second, China's primary insurance industry does not yet have the capacity to deal with catastrophe risks, as property insurance companies do not have the capital to fully cover disaster losses. Lastly, there are still legal restrictions that contradict catastrophe insurers' role in regulations.

Consumers, on the other hand, may reject or ignore the insurers' risk management advice, or indeed have little interest in buying catastrophe

${ }^{224}$ Hjalmarsson \& Bek, supra note 46, at 202. 
insurance at all. The Whole-Nation System turns relying on government's compensation into the rational choice. Moreover, due to the low-probability nature of catastrophe disasters, and the non-rational behavior of consumers, awareness of loss prevention is quite weak. ${ }^{225}$ As a result, the individual's incentive to buy insurance is diminishing.

This situation is beginning to change. Recently, China began to demand the insurance industry complement government actions in addressing catastrophe risk. The 2008 Great Sichuan Earthquake and many other natural disasters over the following years, such as floods and typhoons, made the central government leaders acknowledge the contribution of insurance in regulating policyholders and compensating victims. In 2013, the $3^{\text {rd }}$ Plenary Session of the $18^{\text {th }} \mathrm{CPC}$ Central Committee promulgated the Decision of the Central Committee of the Communist Party of China on Some Major Issues concerning Comprehensively Deepening the Reform. Chapter III is titled "Accelerating the Improvement of the Modern Market System," and expressly states that "we will establish an insurance system for catastrophe risks." Later on, in 2014, catastrophe insurance program trials were launched in Shenzhen, in the Pearl River Delta (a densely populated metropolitan area and also one of the world's most disaster-prone regions), ${ }^{226}$ and in the Chuxiong region in the southwestern province of Yunnan, known to be prone to earthquakes. ${ }^{227}$

${ }^{225}$ T. Yue, et al., The Research on the Establishment of Chinese Catastrophe Insurance and Reinsurance System, 16 FOREIGN INV. CHINA 255 (2013).

${ }^{226}$ According to recent news, in July 2014, the Government of Shenzhen City bought catastrophe insurance policy from PICC on behalf of the residents of the city. This catastrophe insurance framework includes three different parts: The first is the government catastrophe assistance insurance, which is bought by the Shenzhen municipal government to supply the basic assistance for all residents; the second is a catastrophe fund; and the third is private catastrophe insurance. See Gao Song, Shenzhen Signed Catastrophe Insurance Agreement for the First Time, CHINA INS. NEWS (July 10, 2014, 9:19 AM), http://xw.sinoins.com/2014-0 7/10/content 120490.htm.

${ }^{227}$ Reuters, China Says Testing Catastrophe Insurance System, Bus. INS., (Aug. 20, 2014, 12:00 AM), http://www.businessinsurance.com/articl 
With the implementation of new practices in the near future, there is a growing need to explore the effectiveness of catastrophe insurance. This exploration should be carried out by observing and interviewing catastrophe insurance personnel (such as insurers, brokers, actuaries, loss prevention specialists, and claims professionals), a cross-section of consumers through different pilot programs, regulators of catastrophe insurance, and other government officials whose work relates to the Whole-Nation System. This will be a prodigious undertaking, but it will give researchers the opportunity to apply and evaluate regulation by catastrophe insurance in China.

\section{CONCLUSION}

The starting point for this article was a discussion of recent findings in the literature that insurers increasingly act as private risk regulators, substituting or complementing public regulation. Our aim was to examine which technical tools insurers precisely use to execute this task, more particularly in the important domain of the insurance for natural disasters such as flooding and earthquakes. We identified five technical tools that can be employed by insurers to on the one hand control the moral hazard risk and on the other hand provide incentives for disaster risk reduction (risk-based pricing, contract design, loss prevention, claims management and refusal to insure). In line with the literature claiming that insurers act as private regulators, we found that when these technical tools are indeed effectively applied insurers can fulfil their task in contributing to disaster risk reduction. However, when we then examined the possibilities in specific countries (UK, France, US, Japan and Turkey) to apply these technical tools we noticed that the possibilities to do so in practice are often limited, precisely as a result of public regulation. Public regulation would for example prohibit premium differentiation (to promote affordability of insurance) or prohibit a refusal to insure (in order to guarantee an equal

e/20140820/NEWS04/140829990?AllowView=VD13UXk1T3hDUFNCbk JiYkY1TDJaRUt0ajBRV0ErOVVHUT09\#. 
access to catastrophe insurance for all citizens). As a result of those restrictions following from public regulation insurers can in many legal systems often not fully play their role as private risk regulators. It would of course be too early to simply conclude that therefore the interventions by public regulation are necessarily undesirable. However, the interesting challenge is to examine whether it is possible to combine the political desiderata (for example of providing affordable disaster insurance to all) in a model whereby insurers could still apply their technical tools aiming at disaster risk reduction. ${ }^{228}$ That would allow insurers still to play their important role as private regulators, thus substituting or complementing public regulation aiming at disaster risk reduction.

Our contribution mostly focused on the question of how the tools to control moral hazard in catastrophe insurance are implemented in five countries. Another equally interesting question is also why the countries we examined show such a variance in the implementation of tools to control moral hazard. Analyzing that question went beyond the scope of this paper but could undoubtedly be an interesting point for further research.

${ }^{228}$ HOWARD KUNREUTHER, Long-Term Contracts for Reducing Losses from Future Catastrophes, in LEARNING FROM CATASTROPHES: STRATEGIES FOR REACTION AND RESPONSE 235 (Howard Kunreuther \& Michael Unseem, eds., 2010); see generally, HOWARD KUNREUTHER, Reflections and Guiding Principles for Dealing with Societal Risks, in THE IRRATIONAL ECONOMIST: MAKING DECISIONS IN A DANGEROUS WORLD 263 (Erwann Michel-Kerjan \& Paul Slovic eds., 2010). 